\title{
10. Enhancing the social partners and social dialogue in the new world of work: The case of Italy
}

\section{Lorenzo Bordogna}

\section{INTRODUCTION}

Italy has a long experience of bilateral, and partly tripartite, social dialogue, with well-established institutions, actors and practices. In recent times, however, as in most European Union (EU) countries, this experience has been facing severe challenges, owing to both internal and exogenous factors. These include globalization and the still enduring effects of the 2008 economic crisis, aggravated by: a stagnating productivity; persisting dualisms in the economic, social and employment structure; the transformation of the production system and the shift towards a service economy; pressures towards a stronger decentralization of collective bargaining in a context of low inflation; digitalization and technological innovation; and political developments that call into question the role of the social partners in the governance of Italian society (termed 'disintermediation'). All these factors challenge social dialogue as it has been experienced hitherto. After briefly recalling the socio-economic and legal context, this chapter examines, through documentary analysis and interviews with protagonists and experts, how the social partners and public authorities are responding to these challenges.*

\subsection{Socio-economic Context: Population, Economy, Labour Market Indicators}

Italy is a unitary state comprising 20 regions, five of which have special autonomous status, 108 provinces, two of which have special autonomous status, and about 8000 municipalities. At the beginning of 2019 it had a population of 60.5 million (of whom 51.3 per cent are female), making it the fourth largest in the EU. It has increased by 3.6 per cent since 2007 , but has decreased slightly since its 60.8 million peak in 2015 (Table 10.1). Foreign residents on 1 January 2019, not only non-Europeans, made up about 8.5 per cent and the foreign-born population about 10 per cent. With a proportion of 22.6 per cent aged 65 or over in 2018, Italy has the oldest population in the EU.

The Italian economy has experienced difficulties in overcoming the effects of the 2008 crisis (Table 10.2). Only in 2015 was gross domestic (GDP) higher than in 2008. After a sharp decrease in 2009 and 2012 (-5.5 per cent and -2.8 per cent, respectively), GDP has grown in subsequent years to 1.7 per cent in 2017 , slowing down to an estimated 0.1 per cent in 2019 and 0.4 per cent in 2020. Per capita GDP at current prices has slightly increased since 2007 (6.2 per cent), but per capita GDP in purchasing power 


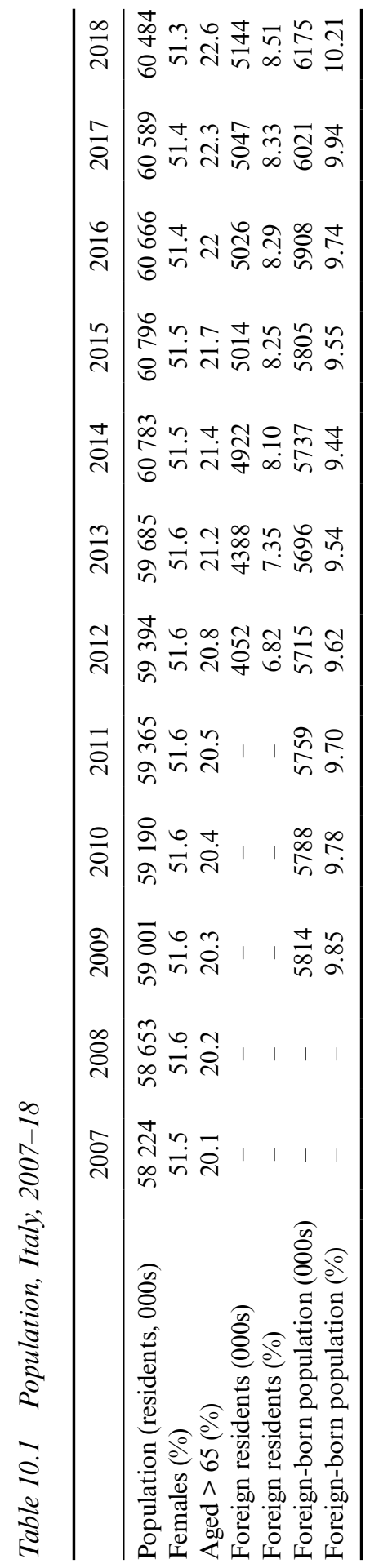




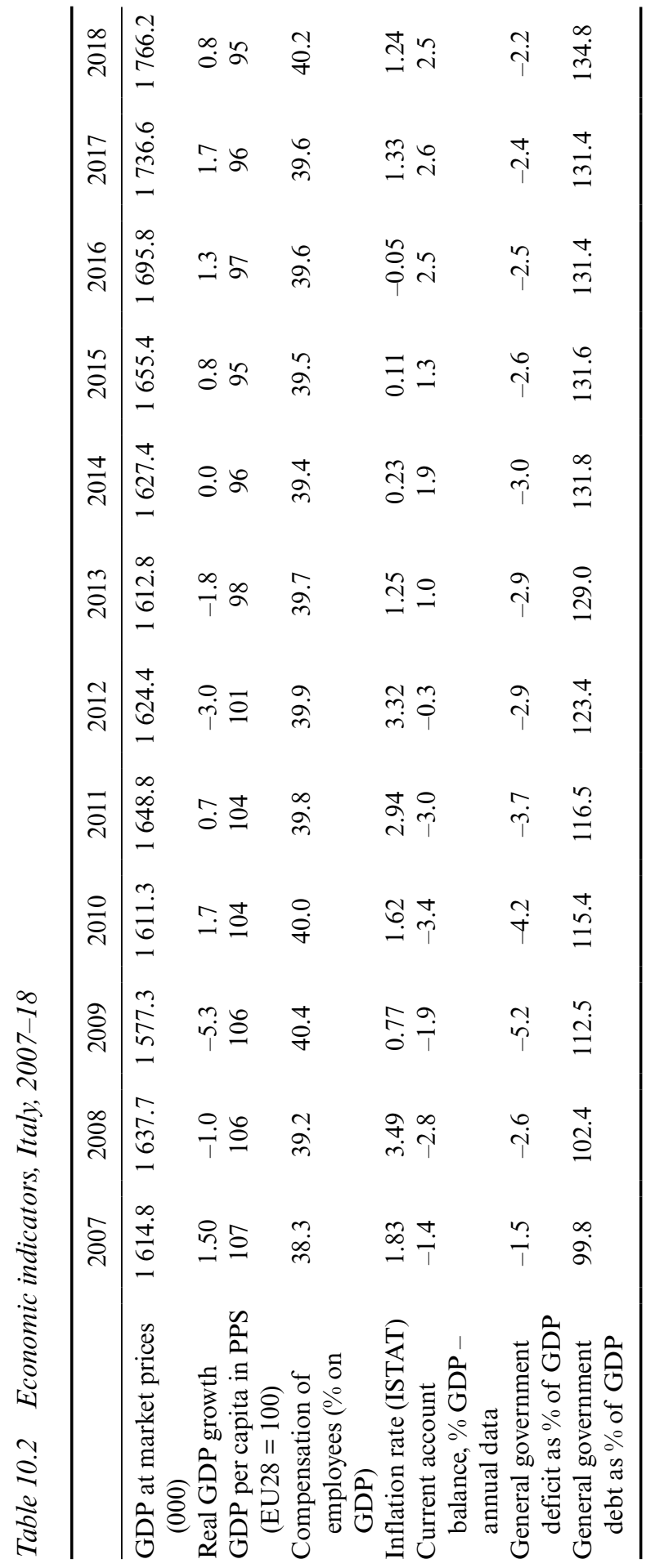


standard (PPS) $($ EU28 = 100) has steadily worsened from 107 in 2007 to 95 in 2018. The weakness of the economy affects Italy's capacity to comply with the EU Stability and Growth Pact. While the public deficit, as in other EU countries, exceeded the 3 per cent threshold during 2009-2011 (-5.2 per cent, -4.2 per cent and -3.7 per cent, respectively), slowly decreasing thereafter, the public debt, which was 99.8 per cent of GDP in 2007, has been stuck at more than 130 per cent since 2014, the second highest in the EU, after Greece. The size of this debt makes any expansionary fiscal policy almost impossible; its annual cost in interest payments amounts to about 4 per cent of GDP ( $€ 65$ billion in 2018).

In the real economy, one of the main problems is the long-lasting stagnation of labour and total factor productivity compared with competing countries. This feature displays wide regional (north versus south) and sectoral (manufacturing versus services sector) disparities, and is also linked to a production system strongly biased towards small and very small companies, as often stressed by the European Commission's Country Report (EU Commission 2016, p. 13; 2018, p. 19). In 2017, only 2.65 per cent of companies in the industrial sector (construction excluded) had 50 or more employees, accounting for less than 50 per cent of total employment in the sector. Despite these weaknesses, however, Italy has a comparatively strong manufacturing and export sector. After suffering during the crisis, the current account balance has been positive since 2013, reaching about 2.5 per cent of GDP in 2018 (Table 10.2), sustained by trade surpluses in goods and services that persisted in 2019 despite the general slowdown in international trade.

With regard to labour market indicators (Table 10.3), Italy has the second lowest employment rate in the EU, after Greece (58.5 per cent in the age group 15-64), substantially the same as in 2007, although increasing slightly since 2013. Much worse is the female employment rate, which is approximately 10 percentage points lower. About 70 per cent of total employment (including self-employed persons) is currently concentrated in the service sector, public administration included, 20 per cent in the industrial sector, slightly more than 6 per cent in construction and slightly less than 4 per cent in agriculture. It was only in the second half of the 1950s that the percentage of total labour force in the industrial sector started to exceed that in agriculture, and only at the end of the 1970s did the service sector take the lead, with an acceleration in the past two decades.

In addition to the low employment rate, Italy has both the third highest unemployment and youth unemployment rates in the EU, after Greece and Spain. The unemployment rate was 9.7 per cent in October 2019, notably above the 6.1 per cent of 2007, although decreasing since the 2014 peak (12.7 per cent). The youth unemployment rate (below 25 years of age) was 32.2 per cent in 2018, 12 percentage points up from 2007, but down from the 2014 peak of 42.7 per cent. Both values are much worse in the southern regions of the country, especially for young women. In 2018 part-time dependent employees, a significant share of whom are non-voluntary part-timers, were about 20 per cent, mainly women. Employees with a temporary contract aged 15 years or over made up 17 per cent of total dependent employees, mainly young workers, while the 19 per cent of those not in education, employment, or training (NEETs) in the 15-24 age group was by far the highest in the EU. Since the late 1990s there has been a proliferation of various types of non-standard, often precarious employment contracts; not only fixed-term, temporary agency and non-voluntary part-time workers, but also semi-autonomous and parasubordinate employees. Finally, the rate of self-employed persons (about three-quarters 


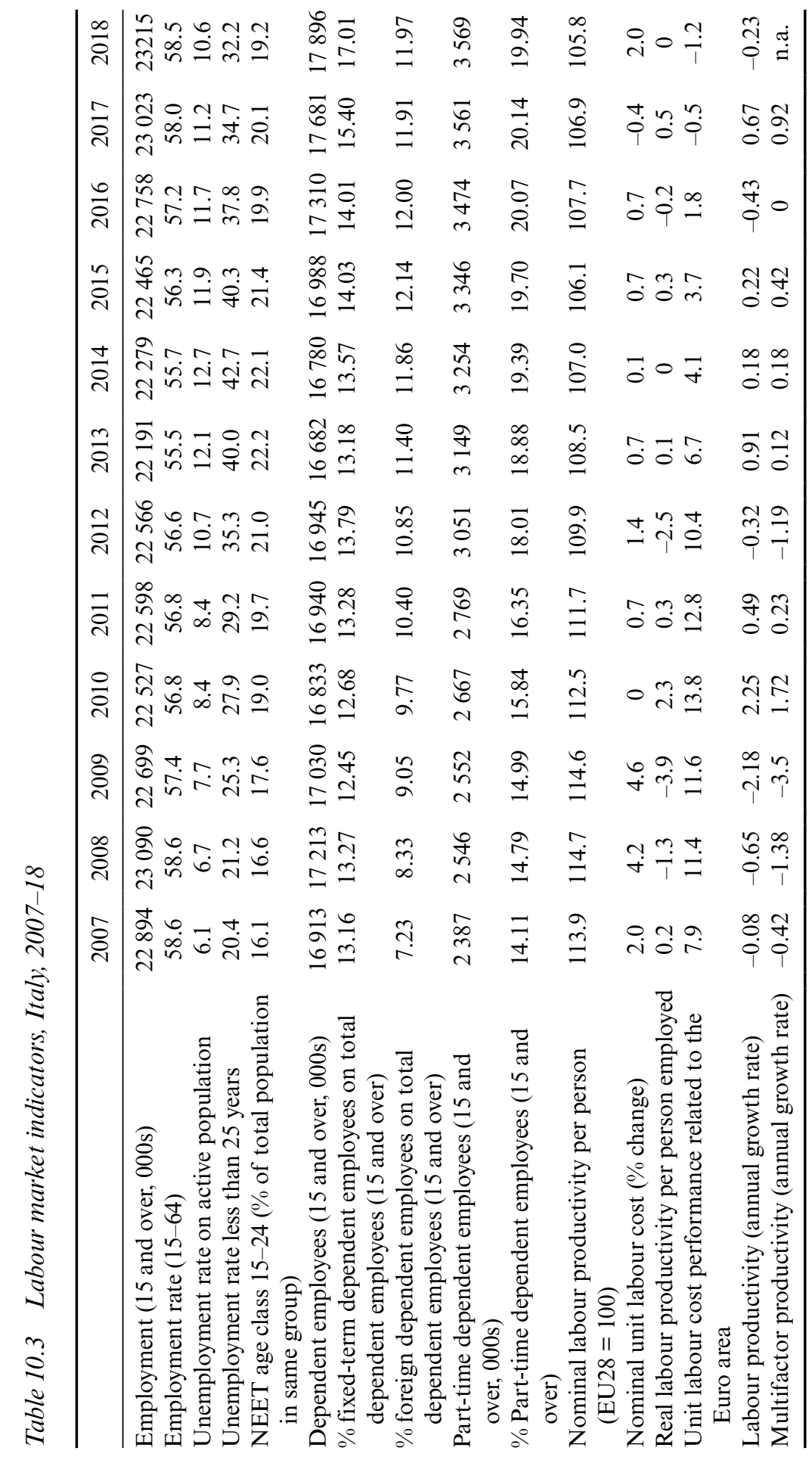


of whom were self-employed without employees) - traditionally quite high in Italy - was close to 23 per cent in 2018, compared with 15.3 per cent in the EU28 and slightly less than 15 per cent in the Eurozone (OECD 2019).

The Italian economic and labour market structure is characterized by deep and often overlapping cleavages. These cleavages are not only between the northern and southern regions of the country, with a few exceptions, but also between manufacturing and services, export-orientated companies and those operating in the domestic market, large and small or very small companies, insiders and temporary workers. The above-mentioned trade surpluses are substantially the product of no more than 4000-5000 medium-sized and large companies, based mainly in the northern and partly in the central regions of the country. These structural and territorial cleavages also affect the dynamics of industrial relations, as well as the companies' capacity for innovation.

\subsection{Main Legal and Institutional Features of the Italian System of Employment Relations}

The Italian system of employment relations is characterized by a high degree of voluntarism. The 1948 Constitution, similar to most democratic constitutions, includes the freedom or right of association, that is, the freedom or right to create interest organizations and to join or leave them (Art. 39, c. 1). The same article also provides for the public registration and legal personality of interest organizations, provided they have a democratic statute, as well as the possibility, in proportion to their membership, to sign collective agreements with compulsory general validity for all firms and employees belonging to the category to which the agreement refers. However, these latter provisions have never been enacted, so that interest organizations, on both sides, remain private actors confined to the private sphere, with no public registration. Likewise, unlike other countries (for instance, Germany), Italy does not have an ordinary law regulating collective bargaining in the private sector, despite the indirect reference to collective agreements in the last comma of Article 39. ${ }^{1}$ The non-implementation of these provisions has not prevented the growth of trade unions and employers' associations in subsequent decades, as well as the wide development of collective bargaining practices, within a voluntarist system. However, this lack of regulation has recently raised several problems owing to the substantial increase in the number of private sector collective agreements signed by bargaining parties (especially, but not only, on the employers' side) with uncertain representativeness. This is the problem of pirate contracts that undercut wages and normative conditions agreed upon by the major organizations (see section 3 in this chapter). ${ }^{2}$

The Italian constitution also includes the (individual) right to strike 'to be practiced within the [ordinary] laws regulating it', without distinction between private and public sector workers. No ordinary legislation had been adopted for four decades, however, until in June 1990 a law was approved regulating the exercise of the right to strike in essential public services, ${ }^{3}$ partly amended in 2000 (Law No. 146/1990 and Law No. 83/2000).

For a number of decades after the 1948 constitution was adopted, the intervention of the law in relationships between the social partners was limited, reflecting the private and voluntary nature of the actors and their relations. In the private sector, this largely still persists. This tradition of legislative abstensionism, however, did not prevent the approval in 1970 of an important piece of legislation, the Statuto dei Lavoratori (Workers 
Statute, Law No. 300, 20 May 1970), with provisions supporting trade union prerogatives in companies. These provisions included the right to establish workplace representation bodies in companies or production sites with more than 15 employees, and to carry out union activities (availability of rooms for union meetings, possibility to hold ballots, leave periods, time off and special protection for union representatives), as well as sanctions against employers' anti-union and discriminatory behaviour. The same legislation also included a very strong job security provision for workers in companies with more than 15 employees, establishing the right of reinstatement (reintegrazione) in case of unlawful individual dismissal - the well-known Article 18, substantially amended in 2015 for newly hired workers (right to economic compensation instead of reintegrazione).

Consistent with the voluntarist character of the system, in Italy there is no formal, legally based infrastructure for social dialogue. Bilateral collective bargaining practices and other types of negotiations are private, voluntary activities, regulated by agreements between the parties. Also, forms of tripartite social dialogue, which do occasionally (less frequently in recent times) occur at national and territorial level, do not have a dedicated, institutionalized infrastructure. The only formal body in which the social partners are institutionally involved in latu sensu forms of social dialogue is the CNEL (National Council of the Economy and Labour) created by the 1948 Constitution (Art. 99), and reformed in 1986 (Law No. 936) and on later occasions. Currently, in addition to the President, its governance structure consists of ten experts, 48 representatives of the productive categories (both workers and employers) and six representatives of social associations, nominated through a decree of the President of the Republic taking into account the numerical and qualitative importance of these categories. Social partners are therefore included together with the representatives of a number of other civil society organizations (the ONG and voluntary/third sector associations). It is an advisory body to the parliament and the government on economic and social matters, with the power of legislative initiative and the right to contribute to the drafting of legislation on the same matters. Its role in the functioning of employment relations has not been particularly relevant for many years. Recently, however, under the presidency inaugurated in 2017, it has been intensively engaged in the measurement of social partners' representativeness, which is a precondition for any action to contrast the proliferation of collective agreements signed by parties with uncertain representativeness that undercut wage and employment conditions (Treu 2019; see section 3 in this chapter).

\section{STRENGTHENING THE REPRESENTATIVENESS OF THE SOCIAL PARTNERS}

The issue of social partner representativeness has two, interrelated features, one common to most countries, the second probably typical of the Italian experience.

The first concerns the social partners' capacity to represent the interests and values of their actual or potential constituencies, through organizational initiatives, labour market and collective bargaining policies, or political lobbying. The results of these activities are at least partly reflected in their respective membership and density rates, which, in turn, depend on the social partners' capacity to retain old members and attract new ones, possibly beyond the traditional areas of representation. In trade unions, for instance, 
as underlined by the interviews, this may imply actions or organizational campaigns to replace workers who retire or exit the unions and to recruit new members, such as young people or precarious workers, who are often more averse to joining unions for cultural or structural reasons. Similarly, in employers' associations, as equally stressed by the interviews, first this includes efforts to deal with the high turnover of companies, especially small companies, during the economic crisis, and to enlarge the area of representation to cover previously neglected sectors or types of companies. In both trade unions and employers' associations, the strategies aimed at strengthening social partner representativeness may also involve actions to improve the internal democracy of these organizations, their ability to reflect or interpret the interests of rank-and-file members through more effective channels of communication and, in general, better mechanisms of internal governance. This is especially true for trade unions (Baccaro et al. 2019), but can also be relevant for employers' associations. Finally, this feature is connected to the social partners' capacity to negotiate bilateral agreements with their counterparts to regulate terms and conditions of employment and labour market matters, as well as to engage government and public authorities in tripartite social dialogue or concertation practices at various levels.

In relation to this first perspective, analysed in this section, a resilience or even a partial recovery of the representative strength of the main social partners can be observed, despite adverse contextual factors and prospective difficulties underlined in the interviews.

The second feature concerns the rules for selecting the organizations entitled to participate in negotiations and to sign agreements with general validity. This feature is connected to a representation system characterized by the presence of a high number of organizations often competing with each other in the same labour market area, on both the workers' side and, even more, the employers' side. Although since the 1950s this has been a traditional characteristic of the Italian system of employment relations, in recent times it has acquired greater relevance and produced increasing tensions, challenging the representativeness of the traditionally dominant actors and, to some extent, the stability of the system itself. There is, however, an asymmetry between the private and the public sector. While in the latter, for reasons explained below, the fragmentation affects exclusively the workers' side, in the private sector it also affects, perhaps above all, employers' representatives. In either sector, the main organizations, and partly the public authorities, have adopted strategies and initiatives to address these challenges, which will be illustrated in section 3 .

\subsection{Trade Unions: Membership and Density Trends}

On the workers side, the scene is still dominated, as in the entire post-war period, by the three largest confederations: CGIL, CISL and UIL. Re-established as a unitary organization at the end of fascism (1943), they split in the late 1940s along ideological and political lines, being mainly linked, respectively, to the Communist and Socialist parties (CGIL), the Christian Democratic party (CISL) and the Social Democratic and Republican parties (UIL). These links weakened during the period of high mobilization of the late 1960s and 1970s, when unity of action tended to prevail, as well as after the collapse of the traditional party system in the early 1990s. However, they have not 
entirely disappeared in the following decades, occasionally giving rise to particularly bitter contrasts, such as those that emerged in connection with the labour market reforms of 2002-03 and 2014-16, and with the 2009 reform of the bargaining system. Currently, these are apparently fading away.

From an organizational point of view, CGIL, CISL and UIL are very large and encompassing organizations, with the strengths and weaknesses proper to organizations with a highly heterogeneous membership (Olson 1965; Walton and McKersie 1965; Kochan 1980). They cover the private and the public sectors, as well as blue-collar and whitecollar workers of all grades of professional qualification, and combine vertical (the industry federations) and horizontal structures, at different territorial levels (province, regional and national level). After several sectoral mergers, owing to changes in the structure of the production system and to financial difficulties, in 2019 the federations affiliated to CGIL, CISL and UIL numbered, respectively, 12, 19 and 16, including the federation of pensioners and that of atypical and temporary agency workers (which may include also unemployed and, partly, self-employed persons). Several mergers have occurred also at territorial level, particularly numerous in the case of CISL.

The strength of the three confederations, excluding pensioners, ${ }^{4}$ is substantial in comparative perspective. The aggregate density rate has varied over the past six decades from a minimum of 25 per cent in 1960 to a maximum slightly over 50 per cent, at the end of the 1970s, with 7.3 million members (excluding pensioners), before two decades of sharp decline (Table 10.4, and Figures 10.1 and 10.2). The lowest point in active membership was touched in 1998 (5.1 million members, according to Visser 2019a), when the three largest confederations together lost almost 30 per cent of their 1980 membership - more than 2 million members - despite a significant increase or an almost identical number of dependent employees (depending on the source ${ }^{5}$ ). From 1999, union membership started to reverse this negative trend, although at a notably slower pace than the increase in employment levels, reaching 6.36 million members in 2018, still 12 per cent less than the 1980 peak but notably more than two decades earlier. Women make up a little less than 50 per cent. Consequently, the density rate also fell sharply for three decades from the 50.5 per cent peak of 1976 to the lowest value of 33.1 per cent in 2006, recovering again slightly to 35.5 per cent in $2018 .{ }^{6}$ This decline was more than offset by the constant increase in the membership of retired workers, rising from 1.6 million members in 1980 to 5.7 million in 2008, in some years equalling or even surpassing the number of active members (especially in CGIL). Afterwards, however, this onset of pensioners stabilized and then started to reverse, and is probably bound to shrink even more in the near future, being mainly the heritage of past militancy, that is, workers who joined the unions in the 1970s (Carrieri and Feltrin 2016, pp. 32-4).

In summary, while membership has fared reasonably well, the density rate has held up less well, although not too badly. In 2018 the largest confederations had 1.2 million active members more than in 2000 , with a 35.5 per cent union density rate. This is among the highest values in the EU after the Nordic countries and a few others (Belgium, Luxembourg and Austria). These results reveal a notable organizational capacity of the three largest confederations to adapt to the deep transformations of the Italian production system, especially the shrinking of the traditional manufacturing sectors, and to react to the adverse pressures of the recent economic crisis, as well as, partly, the political context (government disintermediation policies). They are also due to trade union 
Table 10.4 Membership and density rate of the three largest trade union confederations, Italy, 1960-2018

\begin{tabular}{cccc}
\hline & $\begin{array}{l}\text { CGIL + CISL + UIL } \\
\text { active membership } \\
\text { pensioners excluded (000) }\end{array}$ & Density rate (\%) & $\begin{array}{c}\text { CGIL + CISL + UIL } \\
\text { pensioners (000) }\end{array}$ \\
\hline 1960 & 2885.8 & & - \\
1965 & 3096.2 & 24.7 & - \\
1970 & 4736.2 & 25.5 & - \\
1975 & 6599.1 & 37.0 & - \\
1980 & 7189.0 & 48.0 & - \\
1985 & 6125.5 & 49.6 & - \\
1990 & 5872.4 & 42.5 & - \\
1995 & 5341.2 & 38.7 & - \\
2000 & 5194.5 & 37.3 & - \\
2005 & 5468.1 & 34.4 & 5410.9 \\
2010 & 5974.4 & 33.3 & 5202.6 \\
2015 & 6210.2 & 35.5 & 4829.8 \\
2016 & 6295.4 & 36.6 & 4789.8 \\
2017 & 6361.8 & 36.4 & \\
2018 & 6358.4 & 36.0 & - \\
\hline
\end{tabular}

Source: Up to 2010 is Visser (2019a), then websites of CGIL, CISL and UIL (https://www.cgil.it, https:// www.cisl.it and https://www.uil.it, respectively, accessed on 25 October 2019).

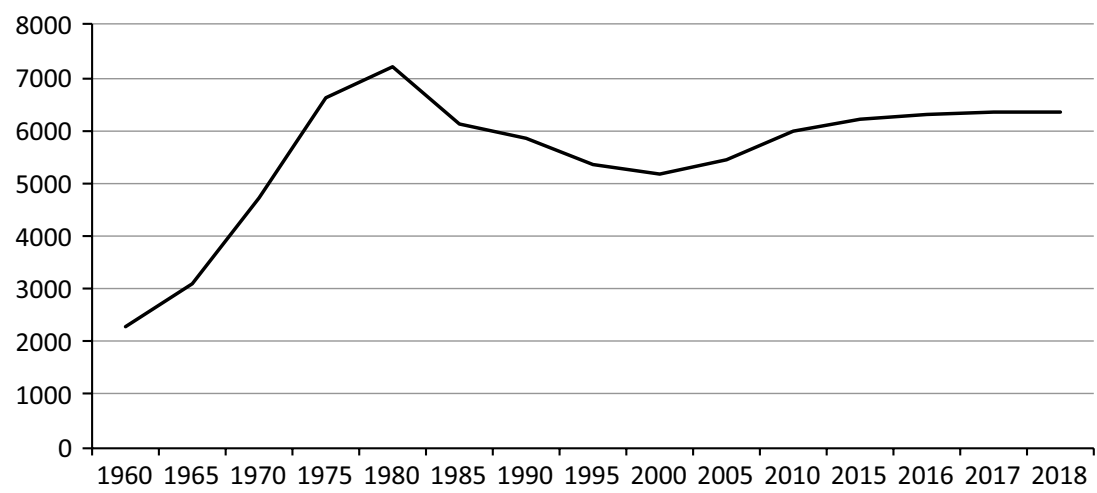

Source: Up to 2010 is Visser (2019a), then websites of CGIL, CISL and UIL (https://www.cgil.it, https:// www.cisl.it and https://www.uil.it, respectively, accessed on 25 October 2019).

Figure 10.1 Membership of the three largest trade union confederations, Italy, 1960-2018 (000s) (pensioners excluded)

efforts to explicitly address the issue of recruiting new members, carried out more or less systematically at confederal, sectoral and territorial levels. Their efforts have included, as for many other EU countries (Pedersini 2010), both organizational measures (creation of specific departments or committees) and policy initiatives targeted at the recruitment 


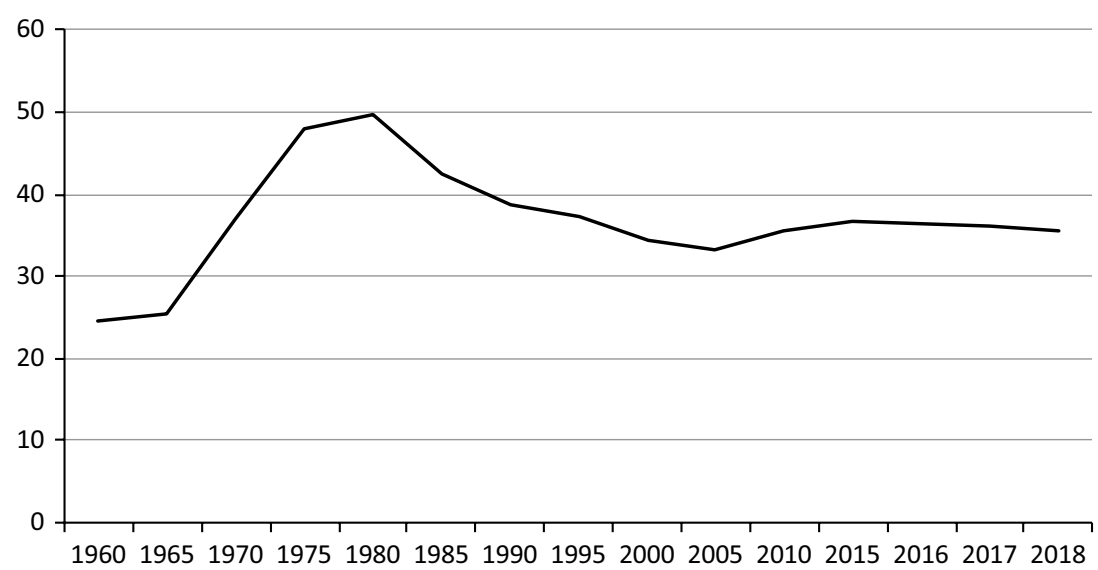

Source: Up to 2010, is Visser (2019a), then websites of CGIL, CISL and UIL (https://www.cgil.it, https:// www.cisl.it and https://www.uil.it, respectively, accessed on 25 October 2019).

Figure 10.2 Density rate of the three largest trade union confederations, Italy, 1960-2018 (pensioners excluded)

process in general $^{7}$ or of specific groups of workers (women, young people, foreign workers and workers with atypical employment contracts).

\subsection{Trade Unions: Changing Internal Composition}

The above-mentioned trends, however, have affected individual categories differently (Table 10.5; Carrieri and Feltrin 2016, pp. 42-4; also Leonardi 2018, pp. 92-4). All private sector categories have lost members, with only two exceptions - commerce and tourism, and banking and insurance ${ }^{8}-$ but not all at the same pace. Capacities differ when it comes to combating the decline in employment levels or taking advantage of employment increases. The manufacturing and industrial sectors, construction excluded, and the transport sector have suffered the largest membership losses, exceeding the decrease in the number of employees or even despite an increase (transport). The membership of the metalworking federations in 2018 is only just over half that in 1978, with notably a greater decline than the decrease in employment levels, although the losses were concentrated in the last two decades of the twentieth century, stabilizing after 1998. Even more pronounced has been the decline of the textile, chemical and energy federations, whose membership in 2018 is little more than one-third of that in 1978, even though employment levels have only halved. This means that in both cases the density rate has declined sharply, losing ten or more percentage points since the late 1970s. By contrast, the commerce sector has almost tripled its trade union membership since the early 1980s, at least partly taking advantage of the extraordinary rise in employment levels, from below 2 million to more than 5 million employees. However, the density rate, slightly lower than the 1978 peak at a little below 20 per cent, is still by far the lowest of all the sectors, explained by factors such as the prevalence of very small firms, the widespread diffusion of precarious jobs and the high turnover of both firms and employees. However, 
particularly in this difficult context, the increase in absolute terms from 382000 members in 1978 (Carrieri and Feltrin, 2016, p. 42) to about 1.1 million in 2018 is astonishing. In the past four years (2015-18) alone, aggregate membership has increased by 17 per cent, with more than 150000 new members, benefiting all three union federations, albeit unevenly. ${ }^{9}$ The only other private sector category that has almost constantly increased its membership - up from 146000 in 1978 to 214000 in 2018 - is that of banking and insurance, despite their obvious difficulties during the recent crisis. With an aggregate density rate of around 42 per cent in 2018, the three unions in this sector have substantially been able to regain their position of 40 years earlier, after a decline to a 35.4 per cent density in 1988.

In transport, membership and employment levels moved in opposite directions until the end of the 1990s, the first declining sharply (in connection with privatization and liberalization), and the second increasing by about 14 per cent. Thereafter, up to 2018 , however, this decline in membership was reversed, together with a stabilization of employment levels. This brought about a small recovery in the density rate, although it remains significantly below its 1978 value. In communications, union membership declined by more than 20 per cent at the end of the 1990s compared with 1978, despite only a minor decrease in employment levels, but then stabilized until 2018. Finally, public administration, not considered in Table 10.5, has substantially maintained or slightly increased its membership since the early 2000 s, although with some variations from year to year.

The upshot of these different trajectories is a radical change in the internal geography of trade union representation (Table 10.6 and Figure 10.3). While in 1981 the manufacturing sectors accounted for about 30 per cent of total (active) membership, public services, private services and agriculture/agro-food industries for about 20 per cent each, and constructions for about 11 per cent, in 2001 the picture was very different

Table 10.5 Membership of some CGIL, CISL and UIL federations, Italy, 1978-2018 $(000 s)$

\begin{tabular}{cccccccc}
\hline $\begin{array}{l}\text { Metal- } \\
\text { workers }\end{array}$ & $\begin{array}{l}\text { Textiles, } \\
\text { chemicals, } \\
\text { energy }\end{array}$ & Construction & $\begin{array}{l}\text { Commerce } \\
\text { and tourism }\end{array}$ & Transport & Communication & $\begin{array}{l}\text { Banking } \\
\text { and } \\
\text { insurance }\end{array}$ \\
\hline 1978 & 1050 & 1108 & 800 & 382 & 516 & 357 & 146 \\
1988 & 765 & 774 & 653 & 361 & 460 & 369 & 173 \\
1998 & 650 & 632 & 584 & 443 & 328 & 285 & 199 \\
2008 & 654 & 529 & 816 & 674 & 364 & 287 & 222 \\
2014 & 656 & 470 & 754 & 901 & 381 & 288 & 212 \\
2018 & 617 & 427 & 663 & 1083 & 401 & 273 & 214 \\
\hline
\end{tabular}

Note: Metalworkers: FIOM CGIL + FIM CIS L+ UILM UIL; Textiles, chemicals, energy: FILCTEM CGIL + FEMCA CISL+UILTEC UIL; Construction: FILLEA CGIL + FILCA CISL + FENEAL UIL; Commerce and tourism: FILCAMS CGIL + FISASCAT CISL + UILTUCS UIL; Transport: FILT CGIL + FIT CISL + UILTRASPORTI; Communications: SLC CGIL + FISTEL and SLP CISL+UILCOM and UILPOSTE UIL; Banking and insurance: FISAC CGIL+FIRST CISL+UILCA UIL.

Source: Up to 2014, Carrieri and Feltrin (2016, p. 42); for 2018, websites of CGIL, CISL and UIL (https:// www.cgil.it, https://www.cisl.it and https://www.uil.it, respectively, accessed on 25 October 2019). 
Table 10.6 Changing geography of union representation: composition of active members by sector, Italy, 1981-2018 (CGIL + CISL + UIL) (percentage in total active membership)

\begin{tabular}{cccccc}
\hline & Manufacturing & Private services & Public services & Construction & Agriculture and agrifood \\
\hline 1981 & 29.6 & 20.1 & 19.8 & 11.2 & 19.3 \\
1991 & 24.6 & 22.5 & 24.1 & 11.0 & 17.7 \\
2001 & 23.8 & 24.7 & 25.6 & 11.8 & 14.1 \\
2011 & 19.5 & 27.7 & 26.0 & 13.8 & 13.0 \\
2014 & 18.9 & 29.9 & 26.0 & 12.7 & 12.5 \\
2018 & 18.7 & 33.0 & 24.7 & 11.4 & 12.3 \\
\hline
\end{tabular}

Source: For 1981-2014, adapted from Carrieri and Feltrin (2016, p. 36); for 2018, author's elaboration of data from the CGIL, CISL and UIL websites (https://www.cgil.it, https://www.cisl.it and https://www.uil.it, respectively, accessed on 25 October 2019).

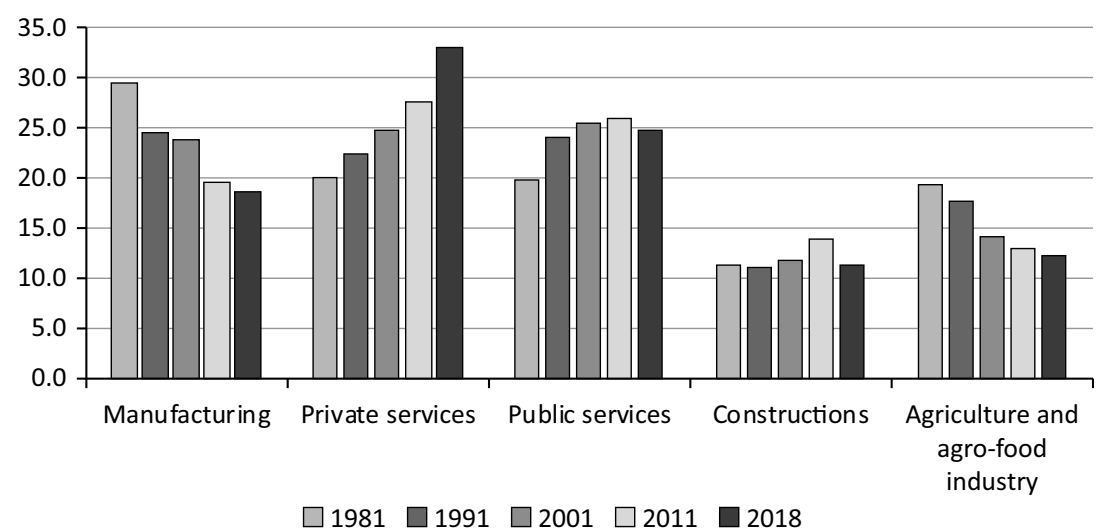

Source: For 1981-2011, Carrieri and Feltrin (2016), p. 36; for 2018 author's elaboration.

Figure 10.3 Changing geography of union representation: percentage composition of active members by sector, Italy, 1981-2018 (CGIL + CISL + UIL)

in 2018. Currently, almost 60 per cent of the active members of CGIL, CISL and UIL are in the service sector, private and public, and less than 20 per cent from traditional manufacturing, with a significant decrease in agriculture and agro-food as well, while the relative weight of construction has remained substantially stable. In particular, the weight of private services has increased strongly and constantly, from 20 per cent to 33 per cent, by far the largest share of active union members. This is a rather composite area of employment, comprising commerce, tourism, transport, communications, and banking and insurance, covered by a number of union federations. The most dynamic category is that of commerce, tourism and services (Filcams-CGIL, Fisascat-CISL and Uiltucs-UIL), which covers a wide range of activities, from wholesale and retail trade to large-scale distribution, from hotels and restaurants to catering firms and tourist services, 
from professional and advanced tertiary services to cleaning industry, domestic work and care-givers. According to an interviewed expert and trade union consultant, among the reasons for the relative ${ }^{10}$ trade union success in organizing such a fragmented area of activity is, paradoxically, the very same precariousness of employment. Precisely because of the high turnover of both firms and employees, typical of many of these activities, 'these workers are in particular need of the (individual) services trade unions can provide to assist them when moving from one job to another'. This amounts to a type of Ghent system without formal Ghent institutions.

\subsection{Representation of Foreign, Atypical and Young Workers}

Other labour market areas in which trade union efforts to organize and represent workers' interests have been effective are foreign and atypical workers, while to some extent greater difficulties have emerged with regard to young workers.

Despite the harsh contrasts raised by the rhetorical abuse of migrants in the Italian political debate, foreign workers are more of a resource than a problem as regards trade union membership. The available information suggests that at least since the beginning of the 2010s foreign workers have made up a significant share of total active union members, at around 13-15 per cent or more. This share is greater than the weight of foreign dependent employees in total dependent employment in the same years, which is approximately 10-12 per cent (see Table 10.3). With nearly 1 million union members in 2011 and a little fewer in 2013, foreign workers are to some extent overrepresented in active union membership compared with their weight in the Italian economy, contributing significantly to compensate the loss of members in the same period, especially in some categories (author's elaboration of Carrieri and Feltrin 2016, p. 38). More recent information on the two larger confederations, CGIL and CISL, confirms this union recruitment among foreign workers (Table 10.7). More than 440000 foreign members of CGIL and more than 340000 foreign members of CISL account for 16.1 and 14.9 per cent, respectively, of total active membership of CGIL and CISL, again exceeding the weight of foreign dependent employees in total Italian dependent employees in the same years (11.9 and 12 per cent, respectively). In both CGIL and CISL, the share of foreign workers is particularly important in particular sectors, such as construction, agro-food, commerce and tourism (including care-givers), but also in metalworking, transport, textiles, chemicals and energy. The pattern is very similar in the two confederations, with the exception of transport and, partly, atypical workers.

Similarly significant is the Italian unions' apparent capacity to expand their area of representation to the varied world of workers with atypical employment contracts, 'a success story also in comparative perspective, often envied abroad', as underlined by an interviewed union official in the sector. This success can be attributed to the strategic choice made by all three confederations at the end of the 1990 s to create separate, ad hoc federations specifically devoted to organizing these workers, irrespective of sector. ${ }^{11}$ The three main groups targeted by these organizations are temporary agency workers, coordinated workers with a para-subordinate employment contract and autonomous/selfemployed without employees; for Nidil-CGIL, unemployed persons and young people in search of their first employment are also a target. The density rate is very difficult to estimate, given the indeterminate and fluid boundaries of these labour market areas; ${ }^{12}$ 


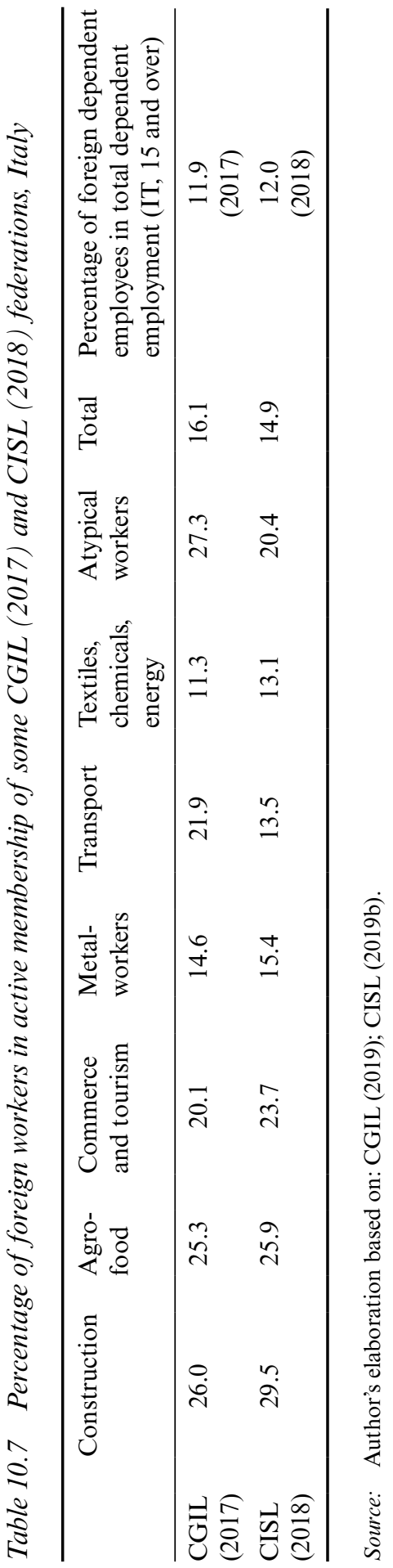


Table 10.8 Membership of atypical worker federations (CGIL + CISL + UIL), Italy, 2010-18

\begin{tabular}{lcccccc}
\hline & 2010 & 2015 & 2016 & 2017 & 2018 & $\begin{array}{c}\% \text { VAR } \\
2015-18\end{array}$ \\
\hline Nidil-CGIL + Felsa-CISL + UILTemp & $100957^{*}$ & 182672 & 204810 & 216855 & 230795 & $26.3 \%$ \\
\hline
\end{tabular}

Note: * Only CGIL + CISL.

Source: Websites of CGIL, CISL and UIL (https://www.cgil.it, https://www.cisl.it and https://www.uil.it, respectively, accessed on 25 October 2019).

but it is probably fairly low. However, the membership trend, despite an extremely high turnover because of the precarious employment conditions (CGIL 2019, pp. 40-41), has been increasing constantly, from a few thousand in the early 2000 s to, in recent years, surpassing the membership of traditional important categories such as banking and insurance (Table 10.8). This growth has been greater than 26 per cent in the past four years alone. It does not fill the gap in the density rate, but it can hardly be considered 'sluggish' (Pedaci et al. 2018, p. 43).

The key to this expansion, as underlined by an interviewed union official, is the provision of (individual) services through a network of institutions and bilateral bodies that are well publicized on the websites of all three unions (see the following section for more details). For the largest component of this group, temporary agency workers, wages and working conditions are determined by the sectoral collective agreement applied by the companies where they temporarily work, and, with regard to certain features, by legislation. Thus, the national collective agreement for temporary work agencies ${ }^{13}$ focuses mainly on measures to protect the 'employment continuity of workers, supporting them also in non-working periods, through activities aimed at the professional reskilling of workers and at the improvement of welfare programmes'. ${ }^{14}$ Many of these measures and programmes are provided by two bilateral bodies, Ebitemp and Formatemp, the first created in 1998 by the first national collective agreement of the sector, and the second in 2000, implementing the 1997 legislation that introduced temporary agency work in Italy. Both are financed by the employers and managed jointly on an equal basis by employers and union representatives. The original mission of Ebitemp was to tackle the problems affecting temporary agency workers during periods of work discontinuity. This mission was later progressively extended to the creation of a comprehensive sectoral welfare system, including supplementary health insurance programmes, integrative pension funds, financial aid for the education of workers and their families, and support for kindergarten attendance. Formatemp's mission is to develop passive and active labour market policies (income maintenance measures and training and retraining activities). For autonomous, self-employed persons without employees, who are often professionals, legal and fiscal services are very important and highly appreciated, provided by the authorized centres for fiscal assistance (CAAFs) managed by the trade union confederations (one for each confederation). As stressed by an interviewed union representative, in a recent survey of self-employed workers, about 90 per cent of respondents declared that they feel best represented by their own accountant. The trade union plan is to provide 
the same services as accountants through the CAAFs, at a lower price, with a view to persuading at least some CAAF clients to unionize. ${ }^{15}$

Unlike the foreign workers and atypical workers, trade union organizational capacity looks less effective for young workers, confirming a feature often underlined in comparative analyses (recently, Visser 2019b). For instance, according to a 2006 article by Jelle Visser, in all the seven countries for which data were available (the USA, the UK, the Netherlands, Ireland, Sweden, Norway and Finland), workers in the 16-24 years age group had a much lower density rate than the overall rate, in some cases well below half (the USA, the UK and the Netherlands) (Visser 2006). A similar difference concerned casual versus standard workers in all four countries for which data are available (UK, Ireland, Netherlands, Norway). The two groups often overlap. Young workers are more likely to have a precarious job, at least at the beginning of their career, and conversely, temporary workers are often young, even if the recent economic crisis has also pushed many adult workers into conditions of precariousness that previously seemed to affect mainly their younger colleagues (as stressed in an interview). It is plausible that such a situation of structural uncertainty may discourage unionization. Italy does not disprove this comparative evidence. The percentage of members below 35 years of age out of the total active CGIL membership was 17.4 per cent in 2017 , and 15.9 per cent of total active CISL membership in 2018. In both, then, it was below the 24 per cent share of dependent employees in the age group 15-34 years in total dependent employees in the same years. As stressed by a confederal union leader 'our language does not reach young workers', referring to traditional communication channels and messages.

In light of these difficulties, all the confederations, and partly the federations, have created structures or positions for handling youth policies, usually reporting to the secretary for organizational matters, and have adopted initiatives specifically targeted to young people. These initiatives include summer or winter youth camps, lasting a few days, in which discussions on work-related topics are mixed with broader political and cultural debates, as well as other activities potentially interesting to young people (sport, music and similar). ${ }^{16}$ To the same purpose, CGIL has long cultivated special links with associations of university students, from which to attract new members and, sometimes, also junior officials. More specific, and perhaps innovative, policies have recently been adopted (see the case study in section 5.1 of this chapter).$^{17}$

\subsection{The Increasing Importance of (Individual) Services}

An increasingly important driver of the recovery of trade union membership is the provision of individual services to workers and citizens at large. With some exceptions, ${ }^{18}$ this is an often neglected area of union activity, to some extent obscured by the primary and more visible trade union missions of collective bargaining and political lobbying. However, it is carefully cultivated and widely practised by all the unions, very important for both membership and financial resources, and well publicized on trade union websites, including the smaller and little representative organizations. Despite the absence of a formal Ghent system, as found in Belgium and the Nordic countries, the Italian trade unions are important providers of a wide variety of individual services to workers and citizens generally, sometimes as intermediaries between them and the state. Services include the employment relationship, unemployment and pension procedures, 
work-related grievances, tax obligations, professional training, welfare and health care, but also tourist or travel packages, supermarket discounts and special insurance packages. The relative importance of providing these services has grown in parallel with the erosion of identity incentives, as in most market democracies, as a way of solving the free-rider problem (Olson 1965) that always plagues the provision of public goods, such as national or company-level collective agreements or legislative measures. In some instances, benefiting from these goods is conditional on union membership; in others, they are open to all, but at a lower cost for union members, as an incentive to unionize (Feltrin and Maset 2007, 2010; Feltrin, 2015).

Three of the most important services are as follows:

1. Assistance to workers and citizens generally, on behalf of the state financial administration, in completing the annual income tax declaration and many other tax obligations and documentation necessary for accessing various types of welfare benefits. These services are provided by the CAAFs created by Law No. 413/1991 (modified in 1997 and 1998), which have to be authorized by the Ministry of Finance. They are promoted and controlled by the trade unions, but are also autonomous. ${ }^{19}$ Users pay a fee for services, with a discount for union members. Moreover, the CAAFs receive financial support from the state. The three major trade union confederations have CAAFs in all regions and provinces, and in most municipalities. ${ }^{20}$ In 2014, for example, CGIL, CISL and UIL CAAFs processed more than 7 million income tax declarations (Table 10.9), to which just under 4 million instances of other services (Isee and Red services; see Carrieri and Feltrin, 2016, pp. 72-3, tables 3 and 4) must be added, totalling almost 11 million. The numbers in 2018, not available in aggregate, are higher (the Bilancio di missione CISL 2017-18 reports 4.571 million), although they have grown at a slower pace than in the past owing to increased competition from other centres not belonging to the main confederations.

2. Assistance to workers and citizens generally, with applications for social security, health care and welfare services, including migration services. This is provided without cost to the user by the patronati sindacali, which are bodies regulated by a 1947 law, amended in 2001 (Law No. 152). The Patronati are financed through a public fund based at the Ministry of Labour, which is provided by a small percentage of total social security contributions paid by dependent employees, distributed proportionately by volume of activity. Not all the services provided by the Patronati receive public financial support, however, and the volume of activity is usually influenced directly by the legislation: for instance, the change in the retirement age introduced at the end of 2011 has reduced the volume of services provided linked to social security applications. In 2012 the three major confederations provided these services in 4.5 million instances.

3. Legal assistance with work-related litigation and legal disputes regarding the employment relationship, or the termination of the employment relationship (such as actions against dismissals and debt recovery). These services are provided by the Ufficio Vertenze (lawsuit or litigation offices), which are much utilized also by not yet unionized workers, and are a very important channel to unionization, since being a union member is a legal prerequisite for assistance at court. 
Table 10.9 Number of instances of services provided by CAAFs and Patronati (CGIL, CISL and UIL), Italy, 2000-2014

\begin{tabular}{lllll}
\hline & 2000 & 2005 & 2010 & 2014 \\
\hline Number of income tax declarations (000s) & 5258 & 6146 & 6702 & 7037 \\
$\begin{array}{l}\text { Number of pension and other services } \\
\text { processed by Patronati (000s) }\end{array}$ & n.a. & $2068^{*}$ & 3680 & $4512^{* *}$ \\
\hline
\end{tabular}

Note: * Only CGIL + CISL; ** 2012.

Source: Carrieri and Feltrin (2016, p. 71, table 2 for the first line; p. 74, table 5 for the second line).

The provision of these individual services is very important not only from the viewpoint of union membership, being an important channel of unionization (Feltrin and Maset 2010), but also for the unions' financial resources. Although difficult to calculate, recent estimates suggest that these services contribute more than 50 per cent of the revenues of the three largest confederations coming from union dues (Table 10.10).

In addition to these services, in recent years the provision of a wide range of health and welfare benefits for employees has also notably increased, laid down in collective agreements at both sectoral and company levels, to some extent compensating for the moderate wage increases of recent bargaining rounds. Benefits include supplementary unemployment, health and pension payments, training activities, financial aid for children's education and, in some instances, even discounts at the supermarket or for fuel. Some of these benefits are provided by a network of Enti Bilaterali, bilateral bodies created by national collective agreements, jointly managed on an equal basis by representatives of the employers and of the trade unions, financed by the parties to the agreement. Although these autonomous bodies are created by the social partners, if they provide services of public interest - for example, those related to health and safety at the workplace, professional and lifelong training, and integrative pensions - they are subject

Table 10.10 Estimated financial resources of CGIL, CISL and UIL, Italy, average 2013-14 (€ million)

\begin{tabular}{lcccc}
\hline & CGIL & CISL & UIL & TOTAL \\
\hline Union dues - active workers & $320-370$ & $260-310$ & $150-180$ & $730-860$ \\
Union dues - pensioners & $150-180$ & $90-120$ & $30-40$ & $270-340$ \\
Union dues - total & $470-550$ & $350-430$ & $180-220$ & $1000-1200$ \\
CAAFs & & & & \\
Min. Finances & $38-41$ & $33-37$ & $13-15$ & $84-93$ \\
Individual fees & $74-81$ & $65-72$ & $26-29$ & $165-182$ \\
Others & $19-22$ & $17-18$ & $7-8$ & $43-48$ \\
Total & $131-144$ & $115-127$ & $47-52$ & $292-323$ \\
Patronati & $100-110$ & $70-75$ & $30-35$ & $200-220$ \\
\hline
\end{tabular}

Source: Carrieri and Feltrin (2016, p. 83). 
to public regulation. Among the most important bilateral bodies are those created in the construction sector, at provincial and regional level, the casse edili (Bellardi 1989), and those in the artisan sector (Nogler 2014), ${ }^{21}$ followed by many others in most bargaining sectors at various levels (Leonardi 2005; Feltrin and Maset 2007; Bellardi and De Santis 2011; Feltrin 2015). The outcome is a very articulated and fragmented system, which in 2013 comprised 29 national bilateral bodies and 386 territorial bodies.

Finally, 2000 legislation introduced the possibility of creating in each (private) sector of economic activity, through inter-confederal agreements between the comparatively more representative social partners at national level, joint funds for employees' occupational training and lifelong learning (fondi interprofessionali). They are authorized and monitored by the Ministry of Labour, and are financed by a contribution of 0.30 per cent of firms' total monthly wage bill. All firms must pay this contribution, whether they decide to participate in these funds or not. In 2014, there were 18 funds, with more than 920 000 participating private firms (69 per cent of potential member firms), covering about 9.6 million employees, that is, more than 80 per cent of private dependent employees (Carrieri and Feltrin 2016, pp. 78-9). These funds may finance training programmes at sectoral or company level, and have played a role in recent years in training programmes related to the National Plan Industry 4.0 and company digitalization.

\subsection{Union Organizations Other than CGIL, CISL and UIL}

In addition to the three major confederations, there are other organizations, that is, independent or autonomous unions. Visser (2019a) reports a total number of seven confederations in 2009 and six in 2017, including CGIL, CISL and UIL. However, these numbers fail to take into account that in the public sector alone, in addition to the three main confederations, four confederations representing managerial staff are (according to the provisional data) admitted to negotiations for the 2019-21 bargaining round, and five different confederations to negotiations for non-managerial staff. Some of these confederations operate in both the public and the private sectors, such as CISAL, CONFSAL, USB and UGL, the latter traditionally linked to right-wing parties. The membership of these independent unions in the private sector is often unknown or obscure. The abovementioned density rates would be higher if these unions were taken into account.

The independent unions are particularly numerous in the public sector and in transport. With regard to the public administration, the provisional list published by ARAN (the agency for the representation of public administration in national negotiations), in view of the 2019-21 bargaining round, includes 90 unions in the central functions sector, 128 in the local functions sector, 116 in the health care sector and 175 in the education sector (Bordogna and Pedersini 2019, p. 211, table 7.4). In total, the independent unions account for about 35 per cent of total public sector union members (excluding managerial staff), while the unions affiliated to the three largest confederations account for between 64 per cent and 70 per cent of the votes cast in the elections of the unitary workplace representation bodies, held in April 2018. Despite this extreme fragmentation, owing to the rules on trade union representativeness introduced in the public sector by 1997 legislation, hitherto unchanged, only seven unions are admitted to national-level negotiations in the central functions sector, including those affiliated to the three largest confederations, four in local functions and six in each of health care and education. 


\subsection{Employers' Associations}

On the employers' side representation is characterized by a comparatively medium-high organization density, partly decreasing since the mid-1990s (Table 10.11) and strongly linked to company size. Fragmented representation also characterizes the employers' associations in the private sector (Feltrin and Mamprin 2013; Feltrin and Zan 2014; Bellardi 2016; Olini 2016, 2017; Bordogna and Pedersini 2019, ch. 3). There are several divisions in sector, type and size of companies, in addition to those based on broad political orientations.

The most important organization is Confindustria, the general confederation of Italian industry founded in 1910, which operates both as a trade association and as an employers' association. It was originally concentrated in the manufacturing (especially mechanical) sector, representing mainly large and medium-large companies. Over time, and accelerating in the past two decades, together with the transformation of the production system, it has evolved into an organization that represents both manufacturing and services firms of any size, on an inclusive basis: there are no size limits and all types of firms are accepted, including cooperatives and public companies. According to the Head of the Area Sistema Associativo of Confindustria: 'The perimeter has changed and so the representation and organizational structure has adapted. Now it is almost fifty-fifty made up of manufacturing and services firms, of any size'. ${ }^{22}$

Confindustria is an umbrella organization with 15 sectoral federations, 19 regional associations and 71 territorial associations, mainly on a provincial basis. In recent decades, there have been several reforms, one in 2002, another in 2014 and the most recent in 2018, as well as a number of mergers, both between sectors and at territorial level, resulting in

Table 10.11 Density of employers' organizations, Italy, 1995-2012

\begin{tabular}{ccc}
\hline & ED & EDpriv \\
\hline 1995 & 71.2 & 64.0 \\
2002 & 69.6 & 62.0 \\
2008 & 68.0 & 60.0 \\
2012 & 64.8 & 56.0 \\
\hline
\end{tabular}

Note: ED - employers' organization density (wage and salaried employees in firms organised in employers' organizations as a proportion of all wage and salary earners in employment); EDpriv - employers' organization density in the private sector.

Source: Visser (2019a).

Table 10.12 Number of firms associated with Confindustria, Italy, 2002-18

\begin{tabular}{cccccc}
\hline 2002 & 2005 & 2009 & 2013 & 2018 & \% VAR. 2002-18 \\
\hline 113307 & 120329 & 142762 & 144302 & 150766 & 33.1 \\
\hline
\end{tabular}

Source: Author's elaboration of data provided by Confindustria. 
Table 10.13 Composition of firms associated with Confindustria by sector, Italy, 2018 (percentage)

\begin{tabular}{ccccc}
\hline Manufacturing & Services & Commerce & Construction & Total \\
\hline 50.3 & 36.4 & 7.5 & 5.8 & 100.0 \\
\hline
\end{tabular}

Source: Data provided by Confindustria.

a more flexible organizational model. Its total revenues from member firms amount to approximately $€ 450-500$ million, mainly from small firms, with, in recent years, territorial structures becoming increasingly important compared with the central confederation. At the end of 2018, Confindustria reported a membership of almost 151000 firms on its website, covering more than 5.4 million employees, allegedly accounting for 34 per cent of Italian GDP. The number of associated firms increased by 33 per cent between 2002 and 2018, constantly and at a rapid pace until 2010-11, followed by a small decrease in 2012-13 and a slight recovery afterwards (Table 10.12).

Half of the member firms are still concentrated in the manufacturing sector (Table $10.13)$, while the other half are in services (36 per cent), commerce ( 7.5 per cent) and construction (5.8 per cent).

Based on these numbers, Confindustria has a seat on all the bodies and institutions in which the legislation envisages employers' representation, including INPS (the Italian Institute of Social Security Institute), all the chambers of commerce, the committees of Cassa Integrazione Guadagni - CIG (wages guarantee and redundancy funds), and other similar bodies.

Regarding composition by firm size, more than eight out of ten member firms about 127000 - have 50 employees or fewer, 13 per cent between 50 and 250, and only 2.6 per cent more than 250 employees (Table 10.14). As a representative of Confindustria with organizational responsibilities said:

practically all large Italian firms in any sector, with 250 employees or more, are associated with CONFINDUSTRIA, as well as a high proportion of medium-large firms. We have no or little room to expand our membership in those segments. ${ }^{23}$ In the past, often firms outside the traditional manufacturing sectors have come to seek our representation, including firms in the ICT sector at the end of the 1980s, as well as the tourist and hotel sector and the media sector. Recent members include organizations unusual for CONFINDUSTRIA, such as the association of large supermarkets (GDO), the association of large bathing establishments, wedding planning firms and NCC associations.

Table 10.14 Composition of firms associated with Confindustria by size of employment, 2018 (percentage)

\begin{tabular}{cccc}
\hline Up to 50 employees & $50-250$ & $>250$ & Total \\
\hline 84.1 & 13.3 & 2.6 & 100.0 \\
\hline
\end{tabular}

Source: Data provided by Confindustria. 
In effect, the interviewed representative continues,

where we still have room to grow is among the small and very small companies, although some of them are hardly organizable and it is debatable whether it should be attempted. In the last (2018) reform there were some proposals, then abandoned, to consider a minimum threshold in terms of employees below which to preclude membership.

In this context, in the past few years Confindustria has adopted more systematic strategies, with marketing techniques (marketing associativo) and recruitment targets assigned to territorial structures, to enlarge its area of representation to encompass small firms, even if there is a limit below which it is hard, and perhaps not desirable, to go. Again according to the Head of the Area Sistema Associativo of Confindustria: 'Here there is a world of entrepreneurs who are very difficult to organize and represent, but that we cannot abandon. ${ }^{24}$ This strategy has included a greater emphasis on the provision of services, particularly needed by small firms that often do not have the necessary resources and competences to produce them in-house, such as services in support of export activities in distant markets. The data in Table 10.14, provided by Confindustria, show that there has been some expansion in this segment, but also that there is still room for growth if we consider the number of firms of this size in the Italian economy.

This is, however, a segment in which the inter-organizational competition for representation is quite strong (Feltrin and Zan 2014; Bordogna and Pedersini 2019, ch. 3). One of the employers' association operating in the industrial sector is Confapi - the 'Italian confederation of small and medium size private firms' - founded in 1947, which, according to its website, ${ }^{25}$ claims more than 80000 member firms (partly also in the transport and services sectors) with more than 800000 employees. On average, therefore, these are very small firms, a segment presumably below the threshold of Confindustria. Another is Confimi, the confederation of Italian manufacturing industry, founded in 2012.

The organizations of the craft sector, especially Confartigianato and CNA, have a greater capacity to compete with Confindustria. The first, founded in 1946, has 12 sectoral federations, 173000 associate firms with employees in 2018 (22 per cent in the construction sector) with about 640000 employed persons; it has its own CAAF, which provides fiscal and tax-related services, as well as its own Patronato, which provides welfare services. The second, the National Confederation of the Artisan Sector and of Small and Medium-Sized Firms, also founded in 1946, declared about 621000 members firms in 2018 with 1.2 million employees. It is the signatory of 17 national collective agreements in various sectors, and the founder of the inter-professional fund for training and lifelong learning for the artisan sector, as well as of the bilateral body EBNA. Both organizations are increasingly trying to expand their area of representation beyond craft and artisan firms, entering into competition with Confindustria in the segment of small firms. Two other, smaller confederations in the artisan sector are CLAAI and Casartigiani.

In the commerce sector, the main confederations are Confcommercio, founded in 1945 , which organizes also professional activities and self-employed persons and declares more than 650000 member firms, and Confesercenti, founded in 1971. Confesercenti claims more than 350000 small and medium-sized member firms operating in commerce, tourism, services, artisanal and industrial activities, allegedly employing more than 1 million people. Three organizations exist in the cooperative sector: Legacoop, founded in 1893 
and currently organizing more than 15000 cooperative enterprises; Confcooperative, founded in 1919 currently organizing 18500 cooperative and social enterprises; and the General Association of Italian Cooperatives (GCI). In the agricultural sector, the main organization is Confagricoltura, founded in 1948, which claims to organize two-thirds of all the enterprises in the sector and covers more than 500000 employees.

All these organizations, and other minor organizations, are divided by sector, type, size and, in some cases, legal status of the represented firms, and partly also along ideological and political lines, although this aspect has been declining in recent decades. They compete for membership in the relevant sector, and often across sectors. This fragmentation of employers' representation in the private sector, even more than the fragmentation on the workers' side, has contributed to the previously mentioned abnormal proliferation of national collective agreements in recent times, often signed by organizations of limited and dubious representativeness. This, in turn, is currently a main challenge for the traditionally dominant social partners and the stability of the system (Bellardi 2016; Olini 2016, 2017; Treu 2019; see section 3 in this chapter).

By contrast, in the public sector there is only one employers' organization, ARAN, created by 1993 legislation, subsequently amended, compulsorily representing all Italian public administrations in collective negotiations at national level (d.lgs n. 93/1993, d.lgs. n. 165/2001). The public employees, both managerial and non-managerial, falling under ARAN's jurisdiction, whose employment contract is regulated through national collective agreements negotiated and signed by ARAN, currently number about 2.6 million. In addition, there are about 500000 public employees, mainly military and police (but also judges, prefects, diplomatic personnel, prison personnel and university professors), whose employment relationship is either unilaterally determined by legislation and/or administrative acts, or regulated through specific procedures carried out at the Ministry of Public Functions, outside ARAN's domain (Bordogna 2016; Bordogna and Pedersini 2019, ch. 7).

\section{SUPPORTING THE AUTONOMOUS ROLE OF THE SOCIAL PARTNERS}

Bilateral social dialogue institutions and practices have a consolidated tradition in the Italian system of employment relations. As anticipated, consistent with the system's voluntarist character, there is no law regulating collective bargaining in the private sector, while it has existed since 1993 (partly 1983) in the public sector. Bargaining practices go back to the 1950s, however, and a two-tier bargaining structure has existed since the early 1960s. The national sectoral (industry-wide) collective agreement (CCNL) is the main pillar, complemented by a second level of negotiations, usually at company level, but at territorial level in some sectors, such as agriculture, construction and artisan enterprises. This two-tier structure was institutionalized, within a vertically coordinated system, by a major reform in July $1993^{26}$ and confirmed by another (albeit controversial) reform in 2009. Bargaining coverage is about 80 per cent or higher, granted by the national industry-wide collective agreements that, if not applied, can be extended through appeal to the courts (see note 2); it is, however, much lower with regard to the second-level negotiations. In the public sector and public administration coverage is 100 per cent, and 
nearly 100 per cent for second-level negotiations. On the eve of the third decade of the new millennium, however, this experience faces a number of problems, especially in the private sector.

Difficulties in national-level negotiations arising from a context of low or negative inflation, started in 2012-13 and still endure. There are also pressures towards greater decentralization of the bargaining system, to the detriment of the role of national, industry-wide and multi-employer collective agreements. Second-level negotiations are mostly limited to large and medium-large firms, in a context of three decade-long stagnating productivity. There are also persisting labour market dualisms, with territorial, sectoral, firm-size cleavages, as well as differences by gender, age and insider/outsider workers, in which platform workers lie. Another problem is the proliferation of national collective agreements signed by parties with uncertain representativeness. Finally, the government has recently tended to downgrade the role of the social partners in the governance of the Italian economy and society (disintermediation), to which the possible introduction of a statutory minimum wage is connected.

Some of these problems are new, others have existed for a long time. For some of them, the social partners have converging interests and attitudes; for others, their interests are in conflict, as stressed in the interviews. In some instances, public policies help in overcoming the difficulties (incentives to engage in second-level negotiations), in others they are lacking (rules on representativeness), while in yet others still they are regarded with suspicion, even hostility, by the social partners (disintermediation and statutory minimum wage).

\subsection{Pressures towards Decentralization, Separate Agreements, and the Issue of Trade Union Representativeness}

The 22 January 2009 reform of the bargaining model, adopted through a (separate) tripartite framework agreement between Confindustria and other employers' associations, on one side, and CISL and UIL, on the other, while confirming the two-tier bargaining structure, left a number of problems open. There were problems, first, because of its character as a separate agreement, since CGIL, the largest trade union confederation, refused to sign it, fearing that the agreement could open the way to unlimited derogations in pejus at company or local level from economic and normative standards defined by national sectoral collective agreements. This might lead to a system of uncoordinated, disorganized decentralization. However, this did not prevent the unitary renewal of almost all national industry-wide agreements, thanks also to a subsequent agreement between Confindustria, CISL and UIL that made derogations at company or local level subject to several conditions and to the final approval of the signatory organizations of the national industry-wide agreement, thus limiting the risk of disorganized decentralization. With two relevant exceptions in the commerce and the metalworking sectors, where the agreements were not signed by the CGIL union federations (respectively Filcams and Fiom). The latter case was particularly problematic, as for a particular period two different national collective agreements were in force: (1) one separate agreement signed in October 2009 only by the CISL and UIL metalworker federations, according to the new 2009 rules, and (2) an agreement signed in January 2008 by all three federations in accordance with the old rules as defined in 1993. This confused situation was further 
complicated by several appeals by Fiom-CGIL to different Italian courts to contest the validity of the 2009 separate agreement, which received different rulings from different tribunals. A similar problem of inter-union rivalries arose in 2010-11 with regard to several second-level agreements in the Fiat group, not signed by Fiom-CGIL, which in many cases was the union with the higher membership.

In all these instances, the underlying issue was one of union representativeness in a context of inter-union rivalries: who represents whom, and who has the power to sign agreements with general validity.

The risk of uncontrolled derogations at company or local level was made even more serious by highly controversial 2011 legislation (Art. 8, Law No. 148), which allowed wide scope to derogate at company and territorial levels from industry-wide collective agreements and, partly, even legal norms, undermining the vertical coordination of the system (Pedersini 2019, p. 348).

The social partners autonomously found a solution to these problems through a number of unitary inter-confederal agreements between Confindustria and CGIL, CISL and UIL in June $2011^{27}$ and May 2013, later incorporated in the more comprehensive agreement of January 2014, the Testo Unico sulla Rappresentanza or TUR (Single Text on Representation), which was later signed or adopted also by other employers' associations (Carrieri 2014).

The agreement included two basic principles widely borrowed from the 1997 legislation for the public sector, still in force. The first of these principles was a precise quantitative criterion to measure the representativeness of trade unions in order to select those admitted to national-level negotiations. This criterion is a representativeness of at least 5 per cent as an average of membership strength and the votes received in the elections of workplace unitary trade union representation bodies (RSU), to be held every three years. Below this threshold, unions are not admitted to national-level negotiations. The second was a majority principle for collective agreements with general validity, applicable to both national industry-wide agreements and company-level agreements. For national industry-wide collective agreements, the criterion requires that the signatory union has (or the signatory unions have together) a representativeness of at least 50 per cent +1 . For company-level agreements, the criterion requires a majority of members of the workplace representation bodies.

These criteria are sufficient, in principle, to resolve the issue of separate agreements owing to inter-union rivalries, leaving only a practical problem of implementation linked to the gathering of membership and electoral data. This problem was a great deal more complicated to overcome in the private than in the public sector, the solution to which took more than five years and a number of agreements and conventions between INPS, CNEL, the Ministry of Labour and the signatory parties. Finally, however, after a September 2019 convention between INPS, the National Inspectorate of Labour, Confindustria, CGIL, CISL and UIL that defines the procedures and responsibilities for gathering the relevant membership and electoral data, all the practical obstacles were removed and the system should be operating from $2020 .^{28}$

It remains a major problem, however. These agreements are binding only for the signatory parties, but not for the organizations, on both sides, that did not sign it or adhere to it. This can be resolved only by legal intervention, which was once opposed by some social partners (especially CISL and Confindustria) in the name of the 
autonomous role of bilateral social dialogue, but is now unanimously accepted and even solicited, as confirmed by all the relevant interviewees. The decision of the government and parliament is crucial, potentially hampered by pressures from organizations possibly damaged by the prospective rules. No such legislation has been approved so far (Treu 2019).

\subsection{The Abnormal Proliferation of National Industry-wide Collective Agreements and the Issue of the Representativeness of Employers' Associations}

Linked to the previous issue, but neglected in the previously mentioned inter-confederal agreements, is the matter of the representativeness of employers' associations, put on the agenda of private sector industrial relations by the recent abnormal proliferation of CCNLs, well documented by CNEL, the National Council for the Economy and Labour (Table 10.15).

The number of national industry-wide collective agreements has constantly increased, from 552 in 2012 to 909 in November 2019. A large number of them are concentrated in the commerce, services and transport sectors (commerce 240, private institutions 111, services firms 47 and transport 69), where the fragmentation of the representation system is traditionally higher. However, they are also numerous in construction (74) and, to a lesser extent, in the manufacturing sectors as well, such as metalworking, chemicals (33 in both) and textiles (28). Often they are signed by organizations with uncertain representativeness also on the employers' side. For instance, only a minority of all the agreements recorded by CNEL in December 2018 belonged to the Confindustria system (68 out of 888 , that is, 7.6 per cent). In some instances, the coverage of the first three agreements in each category of the INPS-CNEL database is high, but in others it is around 70 per cent or even 50 per cent (Table 10.16). Therefore, for a significant part of workers in these

Table 10.15 Number of national sectoral collective agreements in force, recorded in the CNEL archive, Italy, 2012-19

\begin{tabular}{lcl}
\hline & Total number \\
\hline 2012 December & 552 & \\
2013 December & 607 & \\
2014 December & 675 & \\
2015 December & 741 & \\
2016 December & 819 & 68 of which referred to the Confindustria system \\
2017 December & 868 & of which: \\
2018 December & 888 & 33 metalworking sector \\
2019 December & 909 & 74 construction \\
& & 240 commerce \\
& & 111 private institutions \\
& &
\end{tabular}

Source: CNEL (2018, 2019a, 2019b), accessed 10 February 2020 at https://www.cnel.it/Archivio-Contratti/ Notiziari. 
Table 10.16 Coverage of the first three CCNLs, Italy, 2018

\begin{tabular}{|c|c|c|c|}
\hline $\begin{array}{l}\text { Macro-sector (INPS-CNEL } \\
\text { database) }\end{array}$ & $\begin{array}{l}\text { Number } \\
\text { of workers }\end{array}$ & $\begin{array}{l}\text { Number of workers } \\
\text { covered by the first } \\
\text { three CCNL }\end{array}$ & $\begin{array}{l}\text { Coverage of } \\
\text { the first three } \\
\text { CCNL }(\%)\end{array}$ \\
\hline Metalworking & 2362515 & 2309304 & 98 \\
\hline Chemical & 530964 & 412791 & 78 \\
\hline Textile & 381720 & 279347 & 73 \\
\hline Food, agro-food & 421149 & 356352 & 85 \\
\hline Construction, wood, furniture & 712265 & 492594 & 69 \\
\hline Printing sector and entertainment & 283094 & 146536 & 52 \\
\hline $\begin{array}{l}\text { Commerce, tourism, professional } \\
\text { and household services }\end{array}$ & 4704634 & 3797963 & 81 \\
\hline Transport & 805918 & 645573 & 80 \\
\hline Bank and insurance & 463228 & 409755 & 88 \\
\hline $\begin{array}{l}\text { Services (cleaning, } \\
\text { telecommunication, } \\
\text { environmental services) }\end{array}$ & 809942 & 568692 & 70 \\
\hline $\begin{array}{l}\text { Education, health, social and } \\
\text { cultural services }\end{array}$ & 828583 & 649195 & 78 \\
\hline Other & 560426 & 548077 & 96 \\
\hline Total & 12864438 & 10616179 & 82 \\
\hline
\end{tabular}

Source: Text of the Hearing of the CNEL President (T. Treu), House of Representatives, XI Committee, 14 January 2020, table 2.

categories (one out of two, or one out of three) there is the concrete risk of being covered by collective agreements that undercut the wage and normative standards set by the agreements between the comparatively more representative parties. The risk of bargaining dumping is evident, raising problems for the employees and trade unions, but also raising concerns for fair competition between employers.

The issue of the certified assessment of the representativeness of the employers' associations, previously opposed by Confindustria, together with the possibility of a normative or legal regulation on this matter, are probably the main innovations of the most recent inter-confederal agreement between Confindustria and CGIL, CISL and UIL (the Patto della Fabbrica, 9 March 2018). ${ }^{29}$ This new agreement states:

knowing the effective level of representation of both the signatory parties of a CCNL is indispensable if one wants to contrast the proliferation of collective agreements signed by parties with no certified representation, exclusively aimed at providing 'formal justification' for situations of real 'bargaining dumping' that compromise the competition between firms and damage workers.

To this end, the parties agree upon the need to define 'a shared path with the other employers' associations to arrive at a model of certified representation of employers' associations capable of conferring general validity on collective agreements'. Moreover, as for trade union representativeness, the new agreement opens up the possibility of normative or legal regulation of this matter as well. 
However, the prospective procedure for achieving this purpose is full of practical and legal (even constitutional) difficulties, more than in the case of union representativeness. In particular, according to different labour law scholars, Article 39 of the Constitution (freedom of association) prevents the possibility, hypothesized in the agreement, of predetermining the 'objective parameters' (sector/category) within which to measure the representativeness of the parties and, consequently, identify which collective agreement has general validity ('contratto leader'). According to the Constitution, these scholars continue, the parties have the constitutional freedom or right to define for themselves the category of enterprises to which their agreement applies (Ichino 2018; Liso 2018). Resolving this problem is therefore in stalemate, depending only partly on the autonomous role of the social partners, despite the intensive work carried out by CNEL in collaboration with INPS to help them in this process. The intervention of the law, and perhaps a constitutional revision, is again necessary.

\subsection{Public Policies to Promote the Diffusion of Second-level Negotiations and Firm-level Welfare Benefits}

The role of the second level of negotiations in the bargaining structure has long been on the social partners' agenda. In the main reform of 1993, which institutionalized the twotier model within a vertically coordinated structure and an income policy framework, there was an implicit exchange between wage moderation in national sectoral collective agreements, on the one hand, and a greater diffusion of secondary-level negotiations, possibly supported by public incentives, on the other. This exchange, as well as the public incentives, became clearer in the 2009 reform, in which the economic role of national collective agreements was more strictly limited to exclusive protection of the purchasing power of wages against inflation, with no distribution of productivity gains, to be pursued only in second-level negotiations. However, no substantial increase has occurred in the diffusion of company or territorial agreements after the 2009 reform (D'Amuri and Nizzi 2017; Leoni 2017). The available evidence shows that decentralized collective bargaining, as in the past, remains limited mainly to large and medium-large companies (Table 10.17).

The issue has acquired still greater relevance in recent years, within the new economic context of low or negative inflation that started after the new recession and sovereign debt crisis of 2012-13. The national agreements for the period 2013-15 included wage increases in line with the forecast inflation rate, which for the first time turned out to be notably higher than the actual inflation of the period. According to the text of the 2009 reform, this difference (estimated at approximately $€ 70$ a month) should have been given back by workers to the employers in the following bargaining round, which was unrealistic. Thus, all the contract renewals for the 2016-18 (or 2019) period, after a one-year wage freeze and despite significant differences across sectors, ${ }^{30}$ further stressed the crucial role of the second level of negotiations in increasing the real value of wages and salaries, in the form of productivity or performance-related pay and firm-level welfare benefits.

That is why extending second-level bargaining to more companies than in the past has recently become an increasingly important issue on the social partners' agenda, especially that of the trade unions, which see here the only possibility of increasing real wages. The public authorities also have an interest in this issue because of the potential positive effects on company productivity and general economic competitiveness. Public policies 
Table 10.17 Extent of second-level bargaining by industry and company size, Italy, 2012-13 (percentage of enterprises)

\begin{tabular}{lccccc}
\hline & $10-49$ & $50-199$ & $200-499$ & 500 and over & Total \\
\hline Manufacturing & 19.7 & 46.4 & 75.6 & 86.0 & 25.1 \\
Construction & 25.9 & 41.0 & 63.8 & 72.6 & 27.1 \\
Market services & 14.0 & 32.7 & 49.5 & 59.4 & 17.1 \\
Social and personal services & 15.2 & 27.1 & 41.8 & 59.0 & 18.3 \\
Total & 17.5 & 38.5 & 60.5 & 69.1 & 21.2 \\
\hline
\end{tabular}

Source: Pedersini (2019, table 16.5), based on CNEL-ISTAT (2016, ch. 4 and table E1).

adopted in the Stability Law for 2016 (Law No. 208/2015), always substantially renewed thereafter, have introduced significant incentives (tax and social contribution rebates) for employees and employers on wage increases negotiated at company or territorial level, provided that these agreements satisfy certain conditions and are submitted online to the territorial structures of the Ministry of Labour. Moreover, these incentives are higher if monetary wage bonuses are converted into welfare benefits listed in national or companylevel collective agreements (education, health, training, assistance for family members, and so on) and linked to employee involvement arrangements (Leonardi and Pedersini 2018; Leonardi et al. 2018, pp. 216-17). The social partners supported this policy, and in July 2016 Confindustria, CGIL, CSIL and UIL agreed on a type of template of territorial agreements to also facilitate access to these incentives for small and very small companies without workplace trade union representation.

The number of these agreements registered in the database of the Ministry of Labour has notably increased since 2016, reaching a total of 52588 at mid-December 2019 (the last available report at the time of writing), of which about 18000 are still in force (Table 10.18).

From a quantitative viewpoint, it appears to be a success, even though it remains to be seen to what extent these are new agreements, involving previously uncovered companies

Table 10.18 Second-level productivity agreements with tax and social contribution incentives in force on 16 December 2019, registered in the database of the Ministry of Labour, Italy

\begin{tabular}{llllll}
\hline & A & B & C & D & E \\
\cline { 2 - 6 } & $\begin{array}{l}\text { Total agreements } \\
\text { in force on }\end{array}$ & $\begin{array}{l}\text { Of which } \\
\text { company-level } \\
\text { agreements }\end{array}$ & $\begin{array}{l}\text { Of which } \\
\text { territorial-level } \\
\text { agreements }\end{array}$ & $\begin{array}{l}\text { With } \\
\text { welfare } \\
\text { benefits }\end{array}$ & $\begin{array}{l}\text { With employee } \\
\text { involvement } \\
\text { arrangements }\end{array}$ \\
\hline Number & 17937 & 13912 & 4025 & 9461 & 2046 \\
$\%$ (on A) & - & 77.6 & 22.4 & 52.7 & 11.4 \\
\hline
\end{tabular}

Source: Author's elaboration of Ministry of Labour, Premi di produttività, report online, 16 December 2019, Rome, accessed 3 February 2020 at https://www.lavoro.gov.it/notizie/pagine/premi-di-produttivitaonline-il-report-al-16-dicembre-2019.aspx/. 
and territories, or pre-existing agreements suitably adapted to qualify for fiscal incentives (D’Amuri and Nizzi 2017, pp. 15-17; European Commission 2018, p. 36). ${ }^{31}$ From a public policy perspective, the main question is the effectiveness of these agreements in relation to improved productivity. This is what justifies the use of public resources in the amount of $€ 1$ billion in 2019 (D'Amuri and Nizzi 2017, p. 216; European Commission, 2018 , p. 36) to grant tax rebates to approximately 2.5 million beneficiaries (INAPP 2019, estimates until June 2018).

\subsection{Relationships with Government and Political Parties: Disintermediation and the Issue of the Statutory Minimum Wage}

After the period of tripartite concertation in the 1990s, with the basic agreement of July 1993, in the first two decades of the twenty-first century industrial relations have entered a period of more troubled and discontinuous relationships with the government, conditioned by the political orientations of the parties in office and by the worsening economic context. Tensions have emerged on several occasions after the double-dip recession of 2008-09 and 2011-13, often with divisive effects between and within the social partners. Examples are the contrasts with regard to the reform of the bargaining model in 2009, under a centre-right government, or the labour market reform of 2014-15 under the Renzi government, which abolished Article 18 of the Workers' Statute for employees hired after 7 March 2015 with a permanent employment contract, both strongly opposed by CGIL.

If a common feature can be observed in this period, with continuity across different governments, it is the downgrading of social dialogue in the governance of the Italian economy and society. Major reforms have been adopted by the government with little or no consultation and, in some instances, even against the social partners. Sometimes this has occurred in response to crisis, within the stricter rules of EU economic governance. For example, on the occasion of the freezing of public sector collective bargaining and wage increases after 2010, or the major pension reform at the end of 2011 (Monti government) and other austerity measures, or again as regards the first modification of Article 18, a few months later, again under the Monti government. However, the downgrading of social dialogue, at least intermittently, has continued under subsequent governments, often labelled 'disintermediation' to underline that it is a deliberate programme to erode the role of the social partners in national policy-making. This applies to the labour market reform of 2014-15 (the Jobs Act) of the Renzi government, or the partial amendment of this reform in 2018 by the Five Star-Northern League government. It also applies to the introduction of citizenship income in early 2019 and the new rules for early retirement under the same government. In all of these, the social partners were hardly consulted, or were consulted in such unwieldy meetings (involving up to 40 organizations) that discussion was almost impossible or meaningless.

However, there have been interventions with beneficial effects on the role of autonomous social dialogue. This applies, for instance, to the measures to promote second-level bargaining, approved in 2015 by the Renzi government and substantially renewed, with few modifications, by all the budget laws of the following governments. We might also mention the National Plan Industry 4.0, launched in 2016-17 by the Renzi and Gentiloni governments, with the intense involvement of social partners, and confirmed, albeit 
with some amendments, by all the following governments (see section 4 in this chapter). Moreover, the coalition government currently in office, of which the Democratic Party is the second largest component after the Five Stars movement, is paying more attention to the role of social dialogue than its predecessor did.

The most important issues currently on the agenda are probably the regulation of trade union and employer association representativeness, and the statutory minimum wage. The latter issue is controversial. Strongly supported by the largest political party currently in office (the Five Stars Movement), it is substantially opposed by all the social partners, at least with reference to the first unofficial proposals that hypothesized a high value of the minimum wage ( $€ 9$ an hour, before taxes). It has been noted that in some sectors and for some occupations this value would be higher than that fixed by corresponding industry-wide collective agreements. This would inevitably undermine the wage authority of the social partners, not only the trade unions, thereby challenging and eroding their representative capacity. Moreover, both social partners underline that the coverage of national collective agreements is very high in Italy, making the minimum wage less important than in other countries. However, Italy is one of the very few countries in the EU without a statutory minimum wage, and some independent experts, as well as some of the interviewed social partners, stress that the main problem is how a minimum wage could be introduced, and what its relationship would be to the wage standards determined in collective agreements.

In summary, the debate is open and it remains to be seen whether and how the government plans to proceed on this issue. Whatever the solution, it is likely under present circumstances that it will not proceed unilaterally.

\section{SOCIAL PARTNERS AND DIGITALIZATION ${ }^{32}$}

The importance of digitalization on the agenda of the Italian social partners has experienced a qualitative leap since the launch of a public policy on Industry 4.0 in summer-autumn 2016. Prepared by a parliamentary inquiry in February-June 2016 (Commissione Permanente Attività produttive, commercio e turismo, 2016), in which the social partners were also audited, in the following months the government, and in particular the Ministry of Economic Development (MISE), launched the 'Piano Nazionale Industria 4.0 2017-2020', which was incorporated in the Stability Law for 2017 (Law No. 232/2016). The programme aimed at promoting the investments of Italian firms in innovation and research and development (R\&D) in the area of digitalization and new technologies, through direct investments in technological infrastructure and substantial fiscal incentives to firms, amounting to $€ 23$ billion in four years. It also included measures to improve students' capacities in digital skills 4.0 at all levels of the education system, in particular through the enhancement of the technical high schools (ITS) and an increase in the number of graduates in science, technology, engineering and mathematics (STEM) subjects. To date (January 2020), the plan has been refinanced every year in the state budget, despite some uncertainties in the past two years and amendments aimed at also promoting green investments and involving other economic sectors beyond manufacturing, as well as small-size firms. In particular, in 2018 the incentives for activities related to human capital formation and more specifically to workers' training and 
retraining in the area of digitalization and new technologies were subject to the precondition of a company or territorial level agreement with trade unions. ${ }^{33}$ This novelty in a short time led to three national framework agreements on this matter between CGIL, CISL and UIL and, respectively, Confindustria (5 July 2018), Confapi (23 July 2018) and Confimi (2 August 2018); in March 2019 a similar agreement was also reached with the employers' associations of the artisanal sector (Confartigianato, CAN, CLAAI and Casartigiani).

On the issue of workers' upskilling and reskilling, and in general workers' training, although not exclusively related to digitalization and Industry 4.0, it is worth noting also the introduction in the 2016-19 CCNL of the metalworking sector of an individual right for each employee to 24 hours' training. It is a first and limited step, whose implementation has been problematic, but in principle it is important and could be extended in the national agreement currently under renewal.

The original plan also included the creation of a steering committee with the involvement, among others, of the social partners, and the promotion of digital innovations hubs and competence centres to help companies to increase their awareness of these issues and assist them, especially small and medium-sized enterprises, in their innovation programmes.

From the very beginning this government programme has been appreciated by the social partners as a welcome, and long awaited, industrial policy initiative, although the two sides have stressed different features and concerns: investments in equipment and new technologies, on one side, and employment effects, workers' involvement, upskilling and reskilling programmes on the other. Moreover, both social partners have complemented the plan with their own organizational measures and policy initiatives.

\subsection{Trade Union Initiatives}

A few months after the launch of the Plan, CGIL, CISL and UIL submitted a joint document to the government ('Una via italiana a Industria 4.0 che guardi ai modelli europei più virtuosi', Rome, 13 March 2017). The document underlined the importance of three features: giving the steering committee a precise agenda, monitoring the effects of investment on employment and working conditions at company and territorial level, and avoiding a situation in which the incentives benefited only, or mainly, medium-large companies in central and northern Italy. Among the matters of most interest for collective bargaining, CGIL, CISL and UIL stressed working time, work-life balance, wage increases linked to productivity and workers' participation, not only in the organization of work but also the definition of company business plans. The main underlying idea, as later expressed in an interview by the CGIL general secretary, was to allow workers and unions to engage in 'informed bargaining in order to anticipate and govern change rather than simply resist or adjust to its effects' ${ }^{34} \mathrm{~A}$ few examples of company-level agreements inspired by this idea are illustrated in Case Study 2 in section 5.2 of this chapter.

CGIL and CISL also established new organizational units or programmes specifically dedicated to digitalization. At the end of 2016, CGIL set up an 'Office for Work 4.0' (Ufficio Progetto Lavoro 4.0), reporting directly to the general secretary, a 'Consulta Industriale' with internal and external experts, within its industrial policies department, and a collaborative online platform, Idea Diffusa, a virtual laboratory to organize debates 
and exchanges between experts and union officials. ${ }^{35}$ From June 2017, Idea Diffusa also issued a monthly supplement of Rassegna Sindacale, CGIL's journal. In early 2019, two years after the launch of this project, the Office for Work 4.0 published the handbook Contrattare l'innovazione digitale. Una cassetta degli attrezzi 4.0 (Negotiating Digital Innovation. Nuts and Bolts 4.0), with a foreword by the General Secretary. This was presented at CGIL's eighteenth congress on behalf of the national secretarial office, to underline the importance of this initiative to the confederation and the related topic (Cipriani et al. 2018; Gramolati and Sateriale 2019). Together with general analyses, the handbook goes more deeply into specific topics (for instance, negotiating working conditions in the gig economy), presents brief company case studies and provides guidelines for company and territorial level negotiators.

CISL followed a similar course. In February 2017, the General Secretary of the confederation launched 'Laboratory Industry 4.0' (Laboratorio Industria 4.0), within its industry department, as a set of 'competences in support of bargaining and negotiations with the government and employers, with a view to seizing the opportunities of Industry 4.0 and positively managing their effects on working conditions and employment'. The Laboratory, with the collaboration of a few experts from the Polytechnic University of Milan, involved union officials of all CISL industrial and services federations and a number of workers' delegates from 27 companies in 13 sectors. Some of its members, as in CGIL, participated as members of the steering committee initially created by the Ministry of Economic Development to accompany the plan Industry 4.0 (the committee met only twice, however, in 2017 and at the beginning of 2018). The Laboratory also produced two publications, a short introductory report at the beginning and a longer book including general analyses and ten case studies, written mainly by company workers' delegates (CISL 2017, 2019a). In addition, the Laboratory helped to promote various training activities related to Industry 4.0, including a year-long (2019-20) course for workers' delegates and union officials on 'Innovation and work organization 4.0', organized at the confederation's national training centre in Florence.

As an example of the utilization of digital technologies in the internal organizational life of trade unions, the June 2019 organizational conference of the metalworking federation FIM-CISL, under the programme motto 'Smart Union to Drive Change', launched a 'digital union card' project and a 'digital check-off' process, based on blockchain technology. The declared dual aim of the project is to promote a certified and transparent process of unionization (also solving the problem of measuring representativeness), and to improve representation capacities based on the much larger quantity of information made available by the technology. New technologies, in particular social networks, are also used to improve trade unions' communication with workers, especially at small and very small firms. However, as one interviewee stressed, 'new technologies help but do not replace the need for person-to-person relationships'.

\subsection{Employers' Initiatives}

The government Plan Industry 4.0 also involved employers' associations, both in its preparatory steps (the 2016 Parliamentary Inquiry) and in the operational phases following its formal approval in the budget law for 2017 (then renewed for 2018 and 2019). As underlined by the interviewed Confindustria Director of the Area of Industrial Policies, 
social partners' involvement in the formulation and early management of the plan has been very intense, 'with a strong and positive dialogue with trade unions'.

Confindustria, specifically the Area Politiche Industriali, in addition to participating in the steering committee, has been particularly active since early 2017 in the creation of digital innovation hubs (DIH), one of the two structures, together with competence centres, envisaged by the National Plan Industry 4.0 to facilitate innovation. Organized mainly on a regional basis and related to the confederation's territorial associations, in summer 2019 the number of digital innovation hubs under the aegis of Confindustria, in collaboration with other employers' associations (Rete Imprese Italia, comprising associations in the artisanal and commerce sectors), reached 22. These are structured as a network and coordinated by a DIH executive team to try to ensure homogeneity of interventions all over the country, define common strategic guidelines and allow the diffusion of best practices among the different territories. The activities of the DIHs are addressed mainly to small and medium-sized firms, as large companies tend to have their own capacities and resources. Their three main tasks are to raise companies' awareness of the opportunities offered by 4.0 technologies, to support companies in assessing their digital maturity, and to orientate them in the broader innovation system (national and European competence centres, private and public research centres, technological incubators, and so on). In July 2019, the Confindustria DIH network carried out about 430 seminars, meeting more than 5200 companies and making more than 800 assessments of digital maturity (Bianchi 2019; Confindustria 2019). In 2018 and early 2019 a few agreements were reached with important players in the field (Siemens, HP Italy and Google) for the provision of training activities to companies on specific features of 4.0 technologies.

\subsection{Platform Workers and Riders}

As in many countries, the world of platform workers is a growing and much diversified universe, not easily identified. According to a 2018 survey carried out by INAPP (the National Institute for the Analysis of Public Policies), and a hearing of the INAPP Director at the House of Representatives on 25 September 2019, Italian gig workers now number 213150 ( 0.49 per cent of the population between 18 and 74 years of age), of whom approximately 30 per cent provide cleaning services and housework, 25 per cent urban transport services, 15 per cent food delivery, 7 per cent online activities and 23 per cent work for other platforms (INAPP-Nicastro 2019). Their distribution with regard to level of education, gender, age and occupational status compared with the entire INAPP sample is shown in Table 10.19. Compared with the INAPP sample (comprising 45000 persons between 18 and 74 years of age), males outnumber females, workers are younger, sometimes more educated (high school and university degree), less frequently regularly employed, and much more frequently students and people in search of employment. As for the type of employment contract, 14.4 per cent declared they did not know what type of contract was used, 42.1 per cent work with informal agreements, that is, without a proper contract of employment, 19.2 per cent have a contract of occasional collaboration, 6.9 per cent engage in ancillary work and only 2.9 per cent are involved in continuous and coordinated collaboration, with some public insurance cover, while 4.9 per cent are self-employed. Moreover, the survey shows that although almost 40 per cent of these workers are already employed, with another occupation and another 
Table 10.19 Distribution of platform workers and entire INAPP sample by level of education, gender, age and type of occupational status, Italy, 2018 (percentages)

\begin{tabular}{lcc}
\hline & Platform workers & Entire INAPP sample \\
\hline Level of education & 2.8 & \\
Primary school & 34.7 & 4.6 \\
Intermediate & 46.8 & 38.0 \\
High school diploma & 15.8 & 41.1 \\
University degree & & 16.3 \\
\hline Gender & 54.0 & \\
Male & 46.0 & 48.0 \\
Female & & 51.0 \\
\hline Age & 18.9 & \\
18-24 & 25.6 & 9.6 \\
$25-29$ & 20.5 & 7.4 \\
30-39 & 24.2 & 16.7 \\
40-49 & 9.2 & 21.8 \\
50-64 & 1.7 & 29.6 \\
65-74 & & 14.9 \\
\hline Occupational status & 39.8 & \\
Employed & 23.8 & 52.8 \\
In search of employment & 1.0 & 10.6 \\
Pensioner & 17.9 & 13.4 \\
Other non-active & 17.1 & 17.2 \\
Student & & 6.0 \\
\hline
\end{tabular}

Source: INAPP-Nicastro (2019).

source of income, about 30 per cent of them consider their earnings from this activity essential to them surviving financially and 35 per cent had to postpone medical treatment for financial reasons in the year before the survey.

In summary, the survey shows that within this varied world, although a significant percentage of workers have another occupation and utilize platforms to supplement their main income, another important part are exposed to precarious conditions from both an economic and a contractual point of view. These two groups do not always have the same interests.

Riders in the strict sense (in the food delivery sector) make up less than 15 per cent of this whole, numbering approximately 30000 people concentrated mainly in mediumlarge towns and accounting for just 0.1 per cent of total employment. However, they are probably the clearest example of the blurring of boundaries between autonomous and dependent or subordinated work in the context of digitalization, raising complex problems and discussions from a labour law perspective (among others, Voza 2017; Bavaro 2018; Faioli 2019). The public visibility of the riders' issue has been strengthened by protests in recent years, including one involving Foodora employees in Turin in 
October 2016 regarding hourly pay, and a legal case filed by five Foodora workers, who lost their jobs after the 2016 protests, claiming the right to be hired by the company as dependent employees, with all the associated guarantees. This claim was rejected in the first instance by the Turin court (April 2018), but partly accepted by the Court of Appeal (ruling in January 2019), which, although it did not confer on these workers the right to be hired as dependent employees, it did require that they receive treatment equal to that of dependent employees in the logistics sector. The appeal, at the Court of Cassation (24 January 2020), substantially and definitively confirmed this sentence, with a few amendments. This has been welcomed by all the confederal trade unions, as well as the federations of atypical and contingent workers, and particularly by the transport federations, which in July 2018 had reached an agreement with the employers' associations to include riders in the CCNL of the logistics and transport goods sector.

Meanwhile, Parliament has adopted legislation (Law No. 128, 2 November 2019) that brings the regulation of riders and other groups of platform workers closer to the regulation of dependent employees, at the same time conferring a significant regulatory role on the social partners and collective bargaining at both national and decentralized levels.

\section{CASE STUDIES}

\subsection{Case Study 1: Examples of Recruitment Policies - FIM-CISL and FP-CGIL, and Confindustria}

Every year, trade unions and employers' associations have the organizational problem of retaining old members and recruiting new ones, at least ensuring the replacement of natural turnover, which is high in both cases (usually more than 10 per cent for CGIL, CISL and UIL, and significant also on the employers' side, especially among small companies after the 2008 crisis). For trade unions, a particularly critical area is that of young workers; for Confindustria it is small companies.

\section{Increasing youth membership in the metal sector: CISL project}

In 2015-16, the metalworkers federation affiliated to CISL launched a project ('FIM 4.0: A completely different union. Young people in training activity for change') aimed at recruiting young people to become trade union officials (operatori sindacali) in various regional or territorial structures. The idea of this project was not to contact young workers directly in order to unionize them. Instead, it was to renew union political staff with younger personnel, aiming in this way to hire younger skills, such as digital competences, familiarity with social media and languages or channels of communication presumably more attractive to young workers. The potential results in recruitment of young workers were therefore indirect, and expected only in the medium term.

The selection procedure was innovative given the tradition of recruiting union staff only among workers in workplaces. It started with an open call launched in most Italian universities and many high schools, targeted at newly graduated people or students at the end of their academic career. This call registered about 400 applications all over Italy. The second step was the analysis of the candidates' curricula vitae (CVs) and interviews with most of them, at the end of which 20 applicants were selected (with gender equality) for a 
nine-month internship in territorial structures of FIM, mentored by a senior union official. The internship also included forms of online training and three specifically planned, three-day joint training activities, carried out at the FIM national training centre, so that the participants could meet and possibly create a network. At the end of this experience, all but one were hired as junior union officials in different territorial structures. According to one participant we interviewed, it was a very positive experience and the contacts made between the participants were to some extent still active. One of the organizers also gave a very positive evaluation of this project in an interview. However, the project, which ended in October 2016, has not been replicated at national level owing to its complexity. It has been substituted with more flexible internship and apprenticeship programmes at local level for university students (for instance, with the University of Milan), which seem attractive. As a consequence of these renewal programmes, at the end of 2018 the number of FIM union officials below 35 years of age was double that in 2015 (data presented at the national organizational conference of FIM-CISL, Rome, 27-28 June 2019, by Valerio D’Alò, national secretary for organizational matters).

\section{The initiative for public employees by CGIL (FP-CGIL)}

Another interesting example is a recent initiative of the CGIL public sector union (FPCGIL). After the end of the recruitment freeze in all Italian public administrations owing to the austerity policies launched in 2010 , over the next few years approximately 450 000-500 000 recruitments are expected, mainly or exclusively young workers, to be selected through public procedure. In view of this, FP-CGIL has organized a website (www.concorsipubblici.fpcgil.it) with relevant information on the public recruitment procedures of all Italian public administrations. In addition to information, the website also offers (free) online courses to prepare applicants for these public exams. According to a CGIL secretary we interviewed, this initiative has been very well received, with a high success rate in the selection procedures among the participants in these courses. It has also had significant results in relation to new members.

\section{The policies of Confindustria for small companies, young employers and start-ups}

The target of small companies is to some extent a mandatory choice for the associational efforts of Confindustria. This is owing to, first, these companies being numerous in the Italian production system and, second, most of the larger companies are already associated. It is, however, an area in which recruitment and retention of members is difficult, because of high turnover and the competition for membership of other employers' organizations, in particular those of the artisanal sector. In the past few years, Confindustria has developed systematic strategies based on marketing techniques, analysing the potential recruitment area, assigning precise growth targets to territorial associations and periodically monitoring the results achieved. The benefits provided to attract new members in this area are mostly services that are particularly attractive for small companies: forms of support for accessing credit, internationalization through trade fairs, trade missions and other means of contacting distant markets that they would not be able to reach on their own, and other, similar services. These services are very much needed by small companies, since they often lack the necessary resources or skills, while larger companies usually have the capacity to provide them in-house. According to the Confindustria director we interviewed, this policy seems to have been successful. With 
regard to young employers, Confindustria has a special structure dedicated to employers between 18 and 40 years of age (Confindustria Giovani Imprenditori), with about 13000 associates, 60 per cent of whom are in the 30-35 age group. The policy towards people behind start-ups, who are often very young (below 30 years of age), is not to try to associate them through the traditional channels and with the standard requirements (industrial structure, and minimum thresholds for revenues and employment). Instead, it is to facilitate their growth by providing support through access to credit, creation of contacts with potential lenders, and creation of networks with other firms associated with Confindustria, especially small firms, collaboration with which is mutually advantageous. A specific channel for these contacts was recently promoted within the wider initiative Connext, a two-day marketplace launched in early 2019 with the participation of about 1000 companies of various sizes and 7000 participants (entrepreneurs, managers, start-ups, institutions and stakeholders). The digital platform linked to this initiative has registered 40000 users since January 2019. In its second edition (in 2020) Connext also includes a special 'Call for Startups', through which a selected group of start-ups are offered the possibility to participate in the initiative free of charge with their own exhibition desk. The territorial structures of Confindustria also apply special membership conditions to young start-ups, such as reduced association fees, or suspension of fees for a certain period, without limiting access to association services and facilities.

\subsection{Case Study 2. Examples of Company Level Negotiations on Digitalization}

The attitude of trade unions towards digitalization, well expressed in the interview with the General Secretary of CGIL (see note 34), is to 'negotiate the algorithm', meaning that the unions should engage in 'informed bargaining in order to anticipate and govern change rather than simply resist or adjust to its effects'. As also underlined by the General Secretary of CISL, 'innovation is not to be curbed or feared, but accompanied with solutions and concrete opportunities capable of giving workers new factors of security and social advancement' (CISL 2019, pp. 7-8). The idea is that technological innovation is inevitable, and it can have both positive and negative effects on workers and working conditions, depending on how the innovation is introduced and managed. As an RSU representative of a metalworking company said: 'In 4.0 there are many shadow zones but also many opportunities for workers' professional growth, by learning to do new things. This is where the trade unions come in' (quoted in Mancini 2018b, p. 49).

All the cases analysed in Gramolati and Sateriale (2019), CISL (2019a) and others studies (for instance, Campagna et al. 2017; Pero 2015; Pero and Ponzellini 2015; Sai 2017), show that, while the challenge for trade unions would be to anticipate change by negotiating innovation before its introduction (Gramolati and Sateriale 2019 pp. 59, 70-71), this is not always easy to achieve. Nor are there any one-size-fits-all solutions (Mancini 2018b, p. 59). The effects can be ambivalent, even in the same company. On the one hand, they may improve the quality of jobs by reducing repetitiveness, promoting autonomy, facilitating cooperation and teamwork. On the other, they may cut out more of the cognitive content of jobs with little or no development of skills, worsening work-related stress and increasing forms of strict control of workers' behaviour (CISL 2019a, p. 184).

The most recurrent issues in company-level negotiations include vocational training and retraining, health and ergonomic issues, working time, workers' participation and 
the organization of work in general. Job classification is tackled far less often, since it is more complicated, as are, surprisingly, wage and monetary incentives linked to increased productivity, with a few exceptions (CISL 2019a, pp. 193-4).

An example of successful anticipatory bargaining is that of Nuovo Pignone, a General Electric oil and gas company based in Florence, at whose plant all work stations involving digitalization have been equipped with an alert device to signal a technical malfunctioning of the system and issue a work order to the problem-solver team. The RSU has been involved since the beginning in a long, and initially confrontational, negotiation to define the type of information employees have to enter into the device and to limit the use of the procedure exclusively to optimizing the functioning of the plant, avoiding any remote control of individual workers (Mancini 2018b, pp. 55-6; Gramolati and Sateriale 2019, pp. 47, 77). Another agreement on the remote control of workers' activity concerns the use of cyber-security systems at Hewlett Packard (Gramolati and Sateriale 2019, p. 50).

Workers' skills are crucial to avoiding or at least mitigating the potentially negative effects of digitalization on the quantity and quality (polarization, precarization) of work. An individual, subjective right to training, although not necessarily linked to digitalization and apparently little utilized hitherto, was recently included in the 2016-19 metalworkers CCNL, and is on the agenda of the current contract renewal process. Training and retraining, reskilling and upskilling specifically linked to digitalization are often negotiated at decentralized level, in companies or territories undergoing innovation processes, thanks also to the financial incentives made available by the National Plan Industry 4.0 in 2018 and 2019 (for 2020 these incentives have been confirmed, but without the precondition of an agreement with trade unions). Training and retraining, covering soft skills and cognitive abilities in addition to technical matters, are often dealt with together with other issues, such as teamwork and workers' participation. They are crucial not only for the employees, but also for the success of the innovation itself, as many instances testify (CISL 2019a, p. 192). One example of a company agreement in this area is that at Hewlett Packard Enterprise, where in 2017 a training programme 'Nuovo Rinascimento Digitale' ('New Digital Renaissance') was launched, which focused on soft skills to accompany organizational restructuring, together with the online training platform 'Accelerating U', available to every worker, and a job architecture system to help individual employees with their careers (Gramolati and Sateriale 2019, p. 76). Another example is the 'Bonfiglioli Digital Retraining' pilot programme at metalworking company Bonfiglioli, focusing on technical and soft skills, aimed at training 15 employees to become trainers and tutors of other employees (Mancini 2018b, p. 50).

Another important topic in negotiations linked to digitalization is that of the organization of working time, often in connection with forms of teleworking and smart-working (remote). New technologies make it possible to relax the traditional space/time constraints typical of Fordist work organization, opening the way simultaneously to more flexible solutions to meet companies' economic and organizational needs, in a context of increased market uncertainties, but also to more favourable schemes to help workers achieve a better work-life balance (CISL 2019a, p. 193). Examples of negotiations on these matters are frequent in the large supermarket chains, where the decoupling of employees' working time and service hours is well known and more pronounced. As evidenced by two case studies in Campagna et al. (2017, pp. 162-3; also Pero 2017; Ponzellini 2017), in a context of a high proportion of employment feminization, the 
exchange is between flexibility on the part of the employees and greater autonomy in the choice and management of shifts, time off, leave periods and vacation time for a better work-life balance, in addition to monetary incentives.

A similar win-win story with regard to working time is an agreement on teleworking reached in 2013 in a large multinational company, initially limited to a small group of white-collar employees at head office, then extended to all white-collar employees (about 1600 employees). The project has involved a shift of control from physical presence in the company's offices for a specific number of hours to control based on performance and results, abolishing overtime and empowering employees. A trade union survey six months after the launch of the plan has recorded 'more than positive reactions' on the part of employees (Campagna et al. 2017, pp. 168-9).

Another and more recent win-win case is the June 2019 company-level agreement in the Italian plants of Luxottica, regarding an exchange between the stabilization of about 1150 fixed-term and temporary agency workers and a more flexible organization of working time, in addition to employee involvement schemes and company-level welfare benefits (Feltrin and Pero 2019, which offers an extended analysis of this case; Luxottica 2019).

Luxottica is a highly profitable, vertically integrated producer of top-quality glasses, originating in north-east Italy, with approximately 9500 employees in 2019, two-thirds of them women, and a global wholesale network in more than 150 countries. Recently it merged with the French Essilor, a worldwide leading producer of glass lenses. Although the unionization rate is low, the company has a long and well established tradition of strongly cooperative relationships with the internal RSU and the sectoral and territorial unions affiliated to CGIL, CISL and UIL, facilitated by its strong financial position. Over the past two years Luxottica has left the Confindustria territorial associations of the regions where its plants are based, as well as the national sectoral association of glass producers (ANFAO). Unlike Fiat, however, it did not abandon the national industrywide collective agreement signed by ANFAO, whose terms and conditions it applies as the floor for company-level negotiations. The production cycle is subject to high seasonal variability, which the company traditionally copes with by means of overtime and parttime, fixed-term and temporary agency workers. The 2019 company-level agreement, in connection with the introduction of digital technologies in both production and sales, changed this approach completely. The parties decided to stabilize the 1150 or so temporary workers and, in exchange for this, to introduce a new, compulsory part-time incentivized scheme for the stabilized employees involving a 37-hour average week, varying from six hours for five days in the approximately 22 weeks of low demand (usually September-January), and eight hours for five days during the 30 weeks of high production. The average 37 weekly hours also include 30 paid hours of training activities in new technologies. Every year the management announces the expected periods of high and low demand for each department, with possible variations. The monthly wage is paid on the regular basis of 37 hours, irrespective of the variations over time, plus an additional flexibility bonus of $€ 700$ gross a year for each worker. In the future, this scheme will be applied to all newly hired employees. This process of reorganization has been accompanied by a strengthening of the institutions of employee participation, in the form of a new joint management-RSU Organization and Working Time Committee at each production site, with the task of monitoring the implementation of the new working time 
scheme and matching it with the new technologies. The six-hour day in the periods of low demand is much appreciated by the employees (mostly women) for the improvement of their work-life balance, while the 30 hours of training activities in the new technologies are especially appreciated by young workers. The solution of June 2019 comes at the price of a small wage reduction (much less, however, than in the traditional part-time scheme of four hours), compensated by the traditionally rich company-level welfare benefits and accompanied by strengthened employee participation. In return, the company obtains better adaptation to new technologies and a simplification of working-time management. This win-win agreement was facilitated by the company's strong financial position, but also by the tradition of cooperative relations between the social partners.

\section{CONCLUSIONS}

At the beginning of the third decade of the twenty-first century, the Italian social partners and social dialogue show both strengths and weaknesses in the face of the challenges of the new world of work.

As regards the representation system, both the main employers' and workers' organizations have shown good capacity to represent the interests of their constituencies, adapting to changes in the production system and the effects of the 2008 financial and economic crisis. The three largest trade union confederations, after two decades of sharp decline at the end of the twentieth century, especially in the manufacturing sector, have increased their active membership to some extent since the early 2000 s and have stopped, or even slightly reversed, the erosion of the density rate, currently one of the highest in the EU after the Nordic countries and a few others. This has been achieved through a deep transformation of their internal geography and owing to the increasing importance of the provision of (individual) services to retain members and attract new ones. To some extent, employers' organizations have exhibited a similar capacity to resist the effects of the crisis, including the high turnover of firms, despite some more pronounced difficulties.

One problem affecting the representation system on both sides is its increased fragmentation, with the connected inter-organizational rivalries. This is a traditional feature of the Italian employment relations system, linked to its voluntarist character, but greatly aggravated in recent times, especially on the employers' side. This leads, in turn, to the abnormal multiplication of national collective agreements, often signed by parties with uncertain representativeness, which undercut wages and normative conditions agreed upon by the major organizations and challenge the stability of the employment relations system itself. The major social partners have reached important agreements in recent times to regulate this issue in the private sector, following the public sector model, through a procedure of certified measurement of representativeness, based on precise quantitative criteria. Apart from practical difficulties of implementation, however, these rules are binding only for the signatory parties and their affiliated members, and are insufficient to solve the problem. Despite past aversion, the social partners recognize that legal intervention is necessary, as shown by the public sector experience. This calls into question the role of the government and public authorities, and the capacity of the social partners to influence public policies. This capacity, however, has weakened in the 
past decade, partly because of the disintermediation policies practiced by some recent governments, aimed at downgrading the social partners' role in the governance of Italian society. This is a challenge that the social partners have to tackle in the near future.

Strengths and weaknesses can also be observed in respect of bilateral social dialogue. Collective bargaining institutions and practices have resisted and adapted to the crisis. The two-tier bargaining structure, within a model of vertically coordinated decentralization, was reaffirmed by the 2009 reform, despite some serious contrasts between the largest trade unions confederations, which were overcome by a number of important unitary inter-confederal agreements in 2011, 2013 and 2014. National industry-wide collective agreements have been regularly renewed during and since the financial crisis, although with difficulties owing to adverse economic conditions. One source of difficulty is the low, or even negative, inflation rate after the 2012-13 recession. The social partners have reacted to this new economic regime in different ways across sectors, as shown by the different solutions adopted in the chemical and metalworking national collective agreements to adjust wages to inflation. Despite these differences, however, all recent contract renewals, to compensate the modest or almost zero wage increases at national level, have accentuated the role of secondary-level negotiations for the distribution of productivity improvements and the provision of company-level welfare benefits. In this instance, public policies have supported the choices and the role of social partners, providing significant financial incentives to secondary-level agreements linked to productivity goals, and further reinforcing these incentives in relation to participatory arrangements and the transformation of monetary increases into welfare benefits. However, the real effects on the diffusion of secondary-level negotiations, which are currently still confined only or mainly to large and medium-sized companies, remain to be seen. That applies even more to the effects on the improvement of productivity, one of the most serious problem facing the Italian economy.

Another controversial issue, with possible dis-alignments between the government and the social partners, is the statutory minimum wage. The social partners tend to oppose this measure, defending their autonomous role as wage authority, supported by the high bargaining coverage. However, as a few experts have underlined, some - limited - areas are still not covered by national collective agreements, and in some cases, given also the proliferation of pirate contracts, workers may have substandard wages even if covered by national agreements. This remains an open question. The ultimate attitude of the social partners may depend on how a statutory minimum wage is eventually designed and introduced, and its relations with the wage levels decided by collective agreements.

Finally, with regard to digitalization, a process accelerated by recent government policies on Industry 4.0, both social partners are apparently engaged, separately and at times jointly, in trying to seize the potential benefits and to manage possible negative effects through organizational innovations, as well as policy initiatives. All have been involved in the government National Plan Industry 4.0, participating cooperatively in its preparatory work and in the first phases of its implementation. All have created dedicated organizational structures or units to deal with this process, and have promoted related initiatives. For instance, the unions have established groups of experts to study these new problems, online platforms to discuss them and training initiatives for workers' delegates and union officials to learn the appropriate negotiation skills. These themes have started to enter into national, industry-wide collective agreements, as well as company or territorial level 
agreements. Matters such as working time, training and retraining, ergonomic issues, health and safety, control devices, wage incentives and work organization, in addition to employment security, are recurrent topics in these negotiations. All or most of the available case studies show that the social partners may play an important role in conditioning the effects of new technologies, and in some cases even in their design and implementation, through forms of anticipatory bargaining ('negotiating the algorithm' is the formula often utilized by trade unions). Workers' participation, at operational, organizational and strategic level, is an important issue, relevant not only for workers' interests but for the success of innovation itself. The 2018 agreement between Confindustria and CGIL, CISL and UIL, subsequently adopted by other organizations, has opened up a modest but important road in this direction. This is a challenge for both social partners in the new world of work, putting previous scepticism and resistance behind them.

Digitalization also has a dark side, as regards precarization and fragile working and employment conditions, often affecting platform workers, not only riders in the food delivery sector. Recent legislation in this field and the ruling in a legal case brought in 2017 by a small group of Foodora workers give some answers to these issues. In both instances, an important regulatory role is recognized for collective bargaining. This, too, will be a challenge for the social partners in the new world of work.

\section{NOTES}

* I am very grateful to all the protagonists and experts I interviewed (mostly by phone) in June and October-December 2019. They involved six representatives of Confindustria, ten representatives of CISL at national and regional level, five representatives of FIM-CISL at national and territorial level, six representatives of CGIL at national level, one representative of UIL at national level and three experts on labour and employment relations. The responsibility for the content of this chapter is mine alone.

1. By contrast, since a major reform in 1993, legislation exists in the public sector that clearly defines the actors, structure, procedures and coverage of collective bargaining, as well as negotiable matters (d.lgs. $n$. 29/1993; d.lgs. n. 165/2001) (Bordogna 2016; Bordogna and Pedersini, 2019, ch. 7). The unilateral determination of the employment conditions of public employees, which existed in the post-Second World War period, was partly abandoned in the 1970s and early 1980s (Law No. 93/1983). Only in 1993, however, was it definitely substituted by the right to collective bargaining granted to the large majority of public employees, with the exception of some groups that remained under a public law statute (military forces and police, magistrates, prefects, diplomatic personnel, university professors, top-level state managers, the latter privatized and contractualized in 1998). On employment relations in outsourced public services, see Dorigatti (2017), Mancini (2018a) and Mori (2020).

2. Also owing to the failure to implement Article 39 of the Constitution, in Italy there are no easily accessible legal or administrative extension clauses of collective agreements (erga omnes clauses) similar to those existing in other countries (for example, France and Spain). However, individual employees of companies that do not apply the sectoral collective agreement have the possibility (usually assisted by a trade union) to go to court and obtain the application of the standard pay level (minimi tabellari) established by the national collective agreement of the pertinent sector. Thanks also to this mechanism, the bargaining coverage is high, estimated at around 80 per cent or more. However, this mechanism does not solve the problem of the proliferation of collective agreements signed by organizations with little or no representativeness (Treu 2019).

3. Essential public services are defined in this law as those instrumental in ensuring the constitutionally protected rights of the person (to life, health, freedom, security, safety, education, information, communication, mobility, and so on), irrespective of the private or public status of the providers and of their employees.

4. Unlike other countries, in the largest Italian confederations retired workers do not remain members in their original category but are organized in a separate federation of pensioners, whose membership grew constantly until recent years, especially for CGIL and CISL. 
5. According to the ICTWSS_v6.0 source, based on OECD data, the number of wage earners in employment was substantially identical in 1980 and 1998 (14.5 million). Instead, according to the Italian Institute of Statistics the number of dependent employees (permanent + fixed-term contracts) increased by 1 million in the same period, from 13.9 million in 1980 to 14.9 million in 1998 (I.Istat data).

6. The ICTWSS_v6.0 database and Carrieri and Feltrin (2016, ch. 3) present slightly different data over the past four decades concerning membership, although with an almost perfectly overlapping trend. Greater differences between these two sources emerge with regard to the union density rate, owing to a larger aggregate of employees used as denominator in Carrieri and Feltrin (2016); but also in this instance the trend is very similar.

7. All the confederations have annual recruitment targets, monitored mainly systematically through the year, first to replace members who retire or leave the organization for other reasons. These losses, for instance, are estimated by the interviewed confederal secretary for organizational matters to have been approximately 500000 or 600000 active members a year for CGIL; correspondingly lower numbers, but still fairly substantial can be estimated for CISL and UIL. An example of these policy initiatives is the piano di reinsediamento of CGIL, which is an annual plan for financing recruitment projects submitted by decentralized structures and selected by an assessment committee, part of the support being conditional on results. Similar initiatives in support of decentralized, peripheral structures have been adopted by CISL. Another example is the practice of negotiating (and monitoring) annual membership targets by the CISL general secretary in an important region with the lower-level territorial and federal structures of the same region.

8. A third category has increased its membership - temporary agency and atypical workers, whose federations, however, were founded only at the end of the 1990s and are transversal across economic sectors.

9. FILCAMS-CGIL 21 per cent, FISASCAT-CISL 14.1 per cent and UILTCUS-UIL 8.3 per cent.

10. Relative success because, as already noted, the union density rate in this sector is the lowest in Italy.

11. Respectively: Nidil-CGIL, Felsa-CISL (originally Alai and Clacs, merged in 2009), and UILTemp (originally CPO-UIL), all founded in 1998-99. Only a couple of years after that this type of employment contract was introduced in Italian labour legislation. These dedicated structures are an Italian peculiarity (Pedersini 2010; Gumbrell-McCormick 2011; Pulignano et al. 2016; Pedaci et al. 2018). They are flanked by other specific initiatives, such as CGIL's Consulta delle professioni, created in 2003, the association vIVAce created by CISL and Networkers, created by UIL, which offer information and advice, especially legal and tax advice, as well as an arena in which to discuss common problems (Pedaci et al. 2018, p. 43).

12. The Nidil-CGIL website reports a potential area of 600000 temporary agency workers, 920000 parasubordinate workers and 350000 autonomous workers (accessed 19 July 2021 at https://www.nidil.cgil.it_).

13. The last CCNL was signed on 15 October 2019 between Nidil-CGIL, Felsa-CISL, UILTemp and Assolavoro, the national association of temporary work agencies affiliated to Confindustria.

14. CCNL for the category of Agency workers, 15 October 2019, Premessa Generale, p. 2.

15. For instance, Nidil-CGIL recently launched an online consultancy service for self-employed persons and workers in the gig economy, which requires remote pre-enrolment, 'a new frontier of experimentation with quick and effective patterns of first unionization and a new form of membership' (CGIL 2019a, p. 41). Another strategy sometimes adopted at territorial and local level is to offer co-working spaces for selfemployed persons on union premises.

16. A slightly different initiative, targeted at both young shop stewards (delegati sindacali) and young workers in general, is the week-long work camp organized by the network of young metalworkers of FIM-CISL in an area of high organized crime near Naples (Casal di Principe), with social innovation and education projects linked to the world of work smoothing the path to legality. Held for the fourth time in September 2019 , its motto is 'Let's sow the seeds of legality, let's create bonds, let's reap work!'.

17. In addition to the organizational policies described in this paragraph, also important are trade unions' political activities in support of legislation to extend some of the protections enjoyed by standard dependent employees to non-standard workers, especially those not covered by collective agreements (see, for instance, Burroni and Pedaci 2014; Pedaci et al. 2018).

18. For instance, Romagnoli (1980), Bellardi (1989), Bellardi and De Santis (2011), Leonardi (2005) and, more recently, Carrieri and Feltrin (2016, ch. 4, on which much of the information in this paragraph is based).

19. According to the legislation, CAAFs can be promoted also by employers' associations and other organizations as well, provided they meet specific conditions. The number of CAAFs other than those promoted by CGIL, CISL and UIL has increased in recent years.

20. For example, the Bilancio di missione CISL nazionale 2017-2018 reports 2138 CAAF offices (CISL 2019b).

21. In 2011, there were 119 casse edili in the construction sector at regional and provincial level, with 165000 adherent firms, employing about 850000 workers. In the artisan sector there were 21 territorial bilateral 
bodies, coordinated by the central national body (EBNA). A June 2010 inter-confederal agreement in the artisan sector introduced the obligation for all artisan firms, adhering or not adhering to the signatory employers' organizations, to provide all the services agreed upon in the bilateral system (for all this information, see Carrieri and Feltrin 2016, p. 78).

22. Interview with the Head of the Area Sistema Associativo of Confindustria, 5 December 2019 at the headquarters of Assolombarda, Milan. (Assolombarda is the employers' association of the metropolitan area of Milan, and of the provinces of Lodi, Monza and Pavia, and is affiliated to Confindustria.)

23. However, in recent years there have been some defections among the larger firms, such as Fiat at the end of 2011, Aero Piaggio and Ferrari in 2012, Essilor-Luxottica in 2018, and others, although in some cases they have maintained their association to the territorial structures (like Fiat) or to the sectoral organizations of Confindustria. Larger firms have less need of some services provided by Confindustria (for instance support for export activity), while they may be looking for greater flexibility in the management of employment relations in a context of globalized competition.

24. Interview with the Head of the Area Sistema Associativo of Confindustria, 5 December 2019 at the headquarters of Assolombarda, Milan.

25. Website: https://confapi.org (accessed 10 February 2020).

26. The tripartite agreement on incomes policy, collective bargaining model and labour market policies defined as the Italian version of the basic agreements of 1898 in Denmark and 1934 in Sweden.

27. In September 2011, just after the approval of Law No. 148, the parties added a brief but significant clause to this agreement, specifying that they would not utilize the derogation possibilities provided by Art. 8 . But, of course, a legal provision cannot be cancelled by a private agreement, however significant.

28. However, a telephone contact on 24 January 2020 with an official of the Ministry of Labour, e Division IV (Diritti sindacali e rappresentatività, contrattazione collettiva e costo del lavoro), confirmed that the procedure has not been completed yet.

29. 'Contenuti e indirizzi delle relazioni industriali e della contrattazione collettiva di Confindustria e Cgil, Cisl, Uil' ('Contents and guidelines of industrial relations and collective bargaining of Confindustria and Cgil, Cisl, Uil'), Rome, 9 March 2018. For an analysis of this agreement, see Liso (2018); Bordogna (2019).

30. The clearest difference was between the chemical and metalworking sectors. In the first instance, the 2016-18 national collective agreement envisaged a distribution ex ante of wage increases to all employees according to the expected inflation rate, but with an evaluation every year of the difference between real and expected inflation and a corresponding adjustment. This is the novelty: previously, the evaluation and adjustment were at the end of the three-year period of validity. In the metalworking agreement (2016-19), instead, any ex ante increase was abolished, substituted by an ex post increase, starting from the month of July, only after certification of the actual inflation rate of the previous year. In both cases, the outcome is that real wage increases are achievable only through second-level negotiations.

31. According to Bank of Italy estimates (INVIND survey), the percentage of non-financial private firms with more than 20 employees with second-level agreements is stable at around 20 per cent and did not increase between 2010 and 2016 (Banca d'Italia 2017; D'Amuri and Nizzi 2017, p. 14). To avoid opportunistic behaviour, public authorities, including the Ministry of Finance, introduced measures after the 2016 legislation to make tax rebates conditional on actual (certified) productivity increases. The effectiveness of such measures, however, is scarcely assessable (D'Amuri and Nizzi 2017, p. 16).

32. This section is based on interviews with the person responsible for industrial policies at Confindustria, CISL members of the Laboratorio Impresa 4.0, the CISL confederal secretary, formerly coordinator of the Industry Department, the CGIL former coordinator of the Department Industrial Policies and responsible for Ufficio Progetto Lavoro 4.0, CGIL representative of Ufficio Lavoro 4.0 and Progetto Idea Diffusa, and an independent expert from the Politecnico of Milano. Some of the interviewees were audited during the inquiry on 'Industria 4.0' by the Parliamentary Committee on Production Activities, and later participated in the Steering Committee on this matter, created by the Ministry of Economic Development.

33. Law No. 205/2017 (budget law for 2018), Art. 1, 46-56, and DM 4 May 2018, Art. 3, c. 3. The existence of a decentralized agreement with trade unions as a precondition for obtaining the financial incentive was confirmed in the budget law for 2019, but cancelled in the budget law for 2020.

34. Interview with CGIL general secretary, by Chiara Mancini, in 'Idea Diffusa, supplement on Work 4.0', Rassegna Sindacale, April-May 2019, pp. 1-2. According to Eurostat data, in 2016 only 8.3 per cent of Italian workers aged 24-65 participated in training courses, compared with the EU average of 10.8 per cent, and 14.4 per cent in Britain and 18.8 per cent in France.

35. CGIL, 'Report on the Activity of the Ufficio Lavoro 4.0 updated to February 2019'. I am grateful to Chiara Mancini, formerly responsible for the Ufficio Progetto Lavoro 4.0, for sending me this report. See also Mancini (2018a). 


\section{BIBLIOGRAPHY}

Baccaro, L., C. Benassi and G. Meardi (2019), 'Theoretical and empirical links between trade unions and democracy', Economic and Industrial Democracy, 40 (1), 3-19.

Banca d'Italia (2017), 'Relazione annuale', Banca d'Italia, Rome.

Bavaro, V. (2018), 'Questioni in diritto su lavoro digitale, tempo e libertà', in Rivista Giuridica del Lavoro e della Previdenza Sociale, no. 1, pp. 35-64.

Bellardi, L. (1989), Istituzioni bilaterali e contrattazione collettiva. Il settore edile (1945-1988), Milan: Angeli.

Bellardi, L. (2016), 'L'associazionismo dei datori di lavoro: un elemento di fragilità delle relazioni industriali?', Giornale di diritto del lavoro e di relazioni industriali, 151 (3), 403-16.

Bellardi, L. and G. De Santis (eds) (2011), La bilateralità fra tradizione e rinnovamento, Milan: Angeli.

Bentivogli, M., D. Di Vico, L. Pero, G. Viscardi, G. Barba Navaretti and F. Mosconi (eds) (2015), SindacatoFuturo in Industry 4.0, Rome: FIM-CISL.

Bianchi, A. (2019), 'I Digital Innovation Hub di Confindustria, Cernobbio', PowerPoint presentation at the World Manufacturing Forum Annual Meeting 2019, World Manufacturing Foundation, Cernobbio, Como, 25-27 September.

Bordogna, L. (2016), 'Italy: the uncertainties of endless reform. Public service employment relations confronting financial sustainability constraints', in S. Bach and L. Bordogna (eds), Public Service Management and Employment Relations in Europe: Emerging from the Crisis, London: Routledge, pp. 84-111.

Bordogna, L. (2019), 'L'accordo CONFINDUSTRIA - sindacati del 9 marzo 2018 su relazioni industriali e contrattazione collettiva', Giornale di diritto del lavoro e di relazioni industriali, 161 (1), 37-57.

Bordogna, L. and R. Pedersini (2019), Relazioni industriali. L'esperienza italiana nel contesto internazionale, Bologna: Il Mulino.

Burroni, L. and M. Pedaci (2014), 'Collective bargaining, atypical employment and welfare provisions: the case of temporary agency work in Italy', Stato e Mercato, 101 (2), 169-94.

Campagna, L., L. Pero and A. Ponzellini (2017), Le leve dell'innovazione. Lean, partecipazione e smartworking nell'era 4.0, Milan: GueriniNEXT.

Carrieri, M. (2014), 'La lunga fuoriuscita dall'incerta rappresentanza: un approdo finalmente solido?', Giornale di diritto del lavoro e di relazioni industriali, 143 (3), 549-62.

Carrieri, M. and P. Feltrin (2016), Al bivio. Lavoro, sindacato e rappresentanza nell'Italia d'oggi, Rome: Donzelli.

Cattero, B. and M. D’Onofrio (2018), 'Orfani delle istituzioni. Lavoratori, sindacati e le "fabbriche terziarie digitalizzate" di Amazon', Quaderni di Rassegna Sindacale, 1, 7-28.

CGIL (2019), 'Il tesseramento è. Riflessioni dei centri regolatori', paper presented at the eighteenth Congresso nazionale, Bari, 22-25 June.

Ciarini, A. and L. Dorigatti (2017), 'Tra cooperazione e conflitto. Sindacati e organizzazioni autonome nella rappresentanza del lavoro parasubordinato e professionale', Quaderni di Rassegna Sindacale, 18 (1), 127-45.

Cipriani, A., A. Gramolati and G. Mari (eds) (2018), Il lavoro 4.0. La quarta rivoluzione industriale e le trasformazioni delle attività lavorative, Florence: Firenze University Press.

CISL - Laboratorio Impresa 4.0 (2017), Le tecnologie ed il lavoro che cambia, Roma: Edizioni Lavoro.

CISL - Laboratorio Impresa 4.0 (a cura di) (2019a), Le strade dell'innovazione e le sfide per il sindacato. Una ricerca sul campo, Roma: Edizioni Lavoro.

CISL (2019b), 'Bilancio di missione Cisl nazionale 2017-2018', 2nd report, presented at the Conferenza Nazionale Organizzativa, Rome, 9-11 July.

CNEL (2018), Notiziario dell'Archivio Contratti, no. 31 (new series), October (Rome).

CNEL (2019a), Notiziario dell' Archivio Contratti, no. 32 (new series), April (Rome).

CNEL (2019b), Notiziario dell' Archivio Contratti, no. 33 (new series), November (Rome). 
CNEL-ISTAT (2016), Produttività, struttura e performance delle imprese esportatrici, mercato del lavoro e contrattazione integrativa, Rome: CNEL-ISTAT.

Confindustria (2019), 'La rete dei Digital Innovation Hub di Confindustria. Progetti, Competenze, Europa', July, Confindustria, Rome.

D'Amuri, F. and R. Nizzi (2017), 'I recenti sviluppi delle relazioni industriali in Italia', Questioni di Economia e Finanza, Occasional Paper no. 416 (December), Banca d'Italia, Rome.

Dorigatti, L. (2017), 'Condizioni di lavoro nei servizi sociali: disintegrazione verticale e procurement pubblico', Stato e Mercato, 111 (3), 459-87.

European Commission (2016), Country Report Italy 2016, COM(2016) 81 final, Commission Staff Working Document (Brussels).

European Commission (2018), Country Report Italy 2018, COM(2018) 120 final, Commission Staff Working Document (Brussels).

Faioli, M. (2019), 'Attualità di Industry 4.0 nelle relazioni di lavoro. Casi di studio', in CNEL 'XXI Rapporto Mercato del lavoro e contrattazione collettiva', CNEL, Rome, pp. 157-68.

Feltrin, P. (2015), 'Il fenomeno dei servizi sindacali in Italia e in Europa', paper presented at Aisri seminar, Rome, 5 March.

Feltrin, P. and A. Mamprin (2013), 'La misurazione della rappresentatività delle associazioni datoriali. Problemi e metodi', in M. Carrieri and T. Treu (eds), Verso nuove relazioni industriali, Bologna: Il Mulino pp. 367-90.

Feltrin, P. and S. Maset (2007), I servizi nei sindacati (Rome, Edizioni Lavoro).

Feltrin, P. and S. Maset (2010), 'Come resistere al declino. L'opzione dei servizi nei sindacati', Quaderni di rassegna sindacale, 3, 177-210.

Feltrin, P. and L. Pero (2019), 'L'accordo Luxottica', in M. Mascini (ed.), L'Annuario del Lavoro 2019, Rome: Edizioni Il diario del lavoro, pp. 209-15.

Feltrin, P. and S. Zan (2014), Imprese e rappresentanza. Ruolo e funzioni delle associazioni imprenditoriali, Rome: Carocci editore.

Gramolati, A. and G. Sateriale (eds) (2019), Contrattare l'innovazione digitale. Una cassetta degli attrezzi 4.0, Rome: Ediesse.

Gumbrell-McCormick, R. (2011), 'European trade unions and atypical workers', Industrial Relations Journal, 42 (3), 293-310.

Ichino, P. (2018), 'La crepa interna dell'articolo 39', in La Vita. Settimanale della diocesi di Pistoia, n. 26, 8 July, p. 9.

INAPP (2019), 'Contrattazione collettiva e premi di produttività', PowerPoint presentation by F. Bergamante and M. Marocco, Rome, 14 May.

INAPP-Nicastro, P. (2019), 'I mercati digitali del lavoro. Lavoratori delle piattaforme. Evidenze su dati INAPP-PLUS', paper presented to the Eleventh Commissione Camera dei Deputati, Rome, 25 September.

Kochan, T. (1980), Collective Bargaining and Industrial Relations, Homewood, IL: Irwin.

Leonardi, S. (2005), Bilateralità e servizi. Quale ruolo per il sindacato? Rome: Ediesse.

Leonardi, S. (2018), 'Trade unions and collective bargaining in Italy during the crisis', in S. Lehndorff, H. Dribbush and T. Schulten (eds), Rough Waters: European Trade Unions in a Time of Crises, 2nd edn, Brussels: ETUI, pp. 87-115.

Leonardi, S., M.C. Ambra and A. Ciarini (2018), 'Italian collective bargaining at a turning point', in S. Leonardi and R. Pedersini (eds), Multi-employer Bargaining under Pressure. Decentralisation Trends in Five European Countries, Brussels: ETUI, pp. 185-223.

Leonardi, S. and R. Pedersini (eds) (2018), Multi-employer Bargaining under Pressure. Decentralisation Trends in Five European Countries, Brussels: ETUI.

Leoni, R. (2017), 'Efficienza e efficacia della contrattazione integrativa aziendale. Una rassegna della letteratura empirica italiana', Working Papers Series No. 3, Università di Bergamo, Centro Interuniversitario di Ricerca Ezio Tarantelli, Bergamo.

Liso, F. (2018), 'Qualche erratica considerazione sul recente accordo interconfederale Confindustria, Cgil, Cisl, Uil del 9 marzo 2018', 21 April, accessed 20 January 2020 at http://www.bollettinoad apt.it/qualche-erratica-considerazione-sul-recente-accordo-interconfederale-confindustria-cgilcisl-e-uil-del-9-marzo-2018. 
Luxottica (2019), 'Ipotesi di Accordo', 21 June, accessed 27 July 2021 at https://olympus.uni urb.it/index.php?option $=$ com_content\&view $=$ article\&id $=20597: 20191$ uxottica $\&$ catid $=236 \&$ Ite $\operatorname{mid}=139$.

Mancini, C. (2018a), 'Il sindacato di fronte all'economia di internet: "Idea Diffusa”, l'intelligenza collettiva della Cgil', Labour and Law Issues, 4 (1), 40-77.

Mancini, C. (2018b), 'Contrattare l'algoritmo: otto casi aziendali', Quaderni di Rassegna Sindacale, 4, 47-63.

Mori, A. (2020), Employment Relations in Outsourced Public Services: Working Between Market and State, London: Palgrave.

Nogler, L. (ed.) (2014), Gli Enti bilaterali dell'artigianato tra neo-centralismo ed esigenze di sviluppo, Milan: Angeli.

OCSEL-CISL (2018), 'Una contrattazione aziendale sempre più plurale e nuova', 4th Rapporto OCSEL sulla contrattazione decentrata 2016/17, Osservatorio sulla contrattazione di secondo livello, Rome.

OCSEL-CISL (2019), 'Il lavoro cambia ... la contrattazione costruisce le risposte', 5th Rapporto OCSEL sulla contrattazione decentrata 2017/18, Osservatorio sulla contrattazione di secondo livello, Rome.

Organisation for Economic Co-operation and Development (OECD) (2019), 'Country statistical profile. Italy', no. 3, OECD, Paris.

Olini, G. (2016), 'I contratti nazionali: quanti sono e perché crescono', Giornale di diritto del lavoro e di relazioni industriali, 151 (3), 417-36.

Olini, G. (2017), 'Invertire la tendenza alla proliferazione dei contratti nazionali di lavoro', in C. Dell'Aringa, C. Lucifora and T. Treu (eds), Salari, produttività, diseguaglianze. Verso un nuovo modello contrattuale? Bologna: Il Mulino-Arel, pp. 487-512.

Olson, M. (1965), The Logic of Collective Action, Cambridge, MA: Harvard University Press.

Pedaci, M., A. Braga and C. Guarascio (2018), 'Outsourcing of services and collective bargaining coverage in Italy. An analysis on cleaning, ICT and facility management service', RECOVER Project - EU Commission, DG Employment, Social Affairs and Inclusion under Agreement No VS/2016/0351, pp. 1-66.

Pedersini, R. (2010), 'Trade union strategies to recruit new groups of workers', report, European Foundation for the improvement of Living and Working Conditions, Dublin.

Pedersini, R. (2019), 'Italy: institutionalization and resilience in a changing economic and political environment', in T. Müller, K. Vandaele and J. Waddington (eds), Collective Bargaining in Europe: Towards an Endgame, vol. 2, Brussels: ETUI, pp. 337-59.

Pero, L. (2015), 'Industry 4.0: tecnologie, organizzazione e ruolo del sindacato', in M. Bentivogli, D. Di Vico, L. Pero, G. Viscardi, G. Barba Navaretti and F. Mosconi (eds), SindacatoFuturo in Industry 4.0, Rome: FIM-CISL, pp. 22-30.

Pero, L (2017), 'Orari e organizzazione del lavoro: casi di flessibilità vantaggiosa', in Quaderni di Rassegna Sindacale, No. 3, pp. 65-84.

Pero, L. and A. Ponzellini (2015), 'Il nuovo lavoro industriale tra innovazione organizzativa e partecipazione diretta', in M. Carrieri, P. Nerozzi and T. Treu (eds), La partecipazione incisiva. Idee e proposte per la democrazia possibile nelle imprese, Bologna: Il Mulino-Astrid, pp. 45-70.

Ponzellini, A. (2017), 'Fine dell'orario come misura del lavoro? Tecnologie, smartworking, lavoro digitale', Quaderni di Rassegna Sindacale, 3, 31-48.

Pulignano, V., L. Ortiz Gervasi and F. de Franceschi (2016), 'Union responses to precarious workers: Italy and Spain compared', European Journal of Industrial Relations, 22 (1), 39-55.

Romagnoli, G. (ed.) (1980), La sindacalizzazione tra ideologia e pratica, Roma: Edizioni Lavoro.

Sai, M. (2017), 'Industria 4.0: innovazione digitale e organizzazione del lavoro', Quaderni di Rassegna Sindacale, 3, 173-92.

Treu, T. (2019), 'Regole e procedure nelle relazioni industriali: retaggi storici e criticità da affrontare', working paper, Centre for the Study of European Labour Law 'Massimo D'Antona', University of Catania.

Visser, J. (2006), 'Union membership statistics in 24 countries', Monthly Labor Review, January, $38-49$. 
Visser, J. (2019a), 'Database on Institutional Characteristics of Trade Unions, Wage Setting, State Intervention and Social Pacts, 1960-2017' (ICTWSS version 6.0. June), Amsterdam, Amsterdam Institute for Advanced Labour Studies (AIAS).

Visser, J. (2019b), 'Trade unions in the balance', ACTRAV Working Paper, ILO, Geneva.

Voza, R. (2017), 'Il lavoro reso mediante piattaforme digitali tra qualificazione e regolazione', Rivista giuridica del lavoro e della previdenza sociale, 2, 71-82.

Walton, R. and R. McKersie (1965), A Behavioral Theory of Labor Negotiations, New York: McGraw-Hill. 